\title{
Pversagnir og kerfisvillur? Kortlagning á ólíkri stöðu bóknáms- og starfsnámsbrauta á framhaldsskólastigi
}

\author{
Elsa Eiríksdóttir, Guðrún Ragnarsdóttir og Jón Torfi Jónasson
}

\begin{abstract}
Um höfundana $>$ About the authors $>$ Heimildir
Alpjóðlegar rannsóknir hafa sýnt fram á ólíka stöđu bóknáms- og starfsnámsbrauta 1 framhaldsskólum hvað varðar inntak náms, félagslega virðingu, réttlæti og tækifæri til framhaldsmenntunar. Detta hefur einnig verið umræðuefni hér á landi í næstum heila öld. Markmið greinarinnar er að skoða hvernig ólík staða bóknámsog starfsnámsbrauta, með tilliti til virðingar, áherslu og forgangs, birtist 1 íslensku menntakerfi. Umfjöllunin er í premur meginköflum: (1) Hlutverk og áhrif ytri stýringar - pá er sérstaklega vísað til menntastefnu stjórnvalda, til háskólastigsins og til atvinnulífsins; (2) Umgjörð framhaldsskóla og hvað kann að hafa áhrif á val nemenda; (3) Fyrirkomulag kennslu og mismunandi afstaða kennara. Leitast er við að varpa ljósi á pessa pætti með pví að skoða annars vegar námskrár, skýrslur og önnur opinber gögn sem tengjast viðfangsefninu og hins vegar gögn úr rannsókninni Starfshaettir i framhaldsskólum. Niðurstöðurnar ber allar að sama brunni: Ólík staða bóknáms- og starfsnáms er bæði kerfislæg og félagsleg og rætur hennar og tilvist er víða að finna. Birtingarmyndir ólíkrar stöðu komu fram í öllum meginköflunum. Stöðumun var að finna í viðhorfum í opinberri menntastefnu, í aðsókn og aðgengi að framhaldsskólanámi, kennsluháttum í framhaldsskólum og tækifærum að námi loknu. Mikilvægt er að skoða niðurstöðurnar í samhengi við jafnrétti til náms, tilgang menntunar og pað hvernig ráðandi viðhorf lita stjórnsýslu menntamála, samfélagslega afstöðu og starfshætti í skólum, jafnvel bó að opinber stefnumótun einkennist af hinu gagnstæða og yfirlýst stefna sé að efla starfsnám.
\end{abstract}

Efnisorð: Starfsnám, bóknám, framhaldsskóli, námskrár, kennsluhættir, menntakerfi.

\section{Inngangur}

Ólík staða bóknáms- og starfsnámsbrauta á framhaldsskólastigi hefur löngum verið til umræðu í nágrannaríkjum okkar og víðar (sjá til dæmis CEDEFOP, 2014; Lasonen og Young, 1998; Nylund, Rosvall, Elsu Eiríksdóttur, Isopahkala-Bouret, Niemi og Guðrúnu Ragnarsdóttur, 2018; Parkes, 1993) og er pá yfirleitt vísað til pess að starfsnám njóti ekki sömu virðingar og forgangs og bóknám í hugum fólks. Staðan birtist til dæmis í mismunandi félagslegri virðingu, ólíkri áherslu í inntaki náms, mismun á ætlaðri getu nema sem velja hvora leiðina fyrir sig og mismunandi möguleikum til áframhaldandi náms.

Drátt fyrir yfirlýsingar menntayfirvalda og ýmissa hagsmunaaðila í gegnum tíðina um mikilvægi pess að efla starfsmenntun og auka aðsókn í starfsnám telur Ríkisendurskoðun (2017) lítið hafa breyst. Dvert á móti hefur nýnemum í starfsnámi farið fækkandi á síðustu tveimur áratugum (Hagstofa Íslands, 2018a) pótt um helmingur nemenda í framhaldsskóla telji verklegt nám henta sér betur (Menntamálastofnun, 2018a). 
Markmið greinarinnar er að kortleggja ólíka stöðu bóknáms- og starfsnámsbrauta í íslenskum framhaldsskólum. Umfjöllun okkar skiptist í prjá meginkafla: (1) Hlutverk og áhrif ytri stýringar - pá er sérstaklega vísað til menntastefnu stjórnvalda, til háskólastigsins og til atvinnulífsins; (2) Umgjörð framhaldsskóla og hvað kann að hafa áhrif á val nemenda; (3) Fyrirkomulag kennslu og mismunandi reynsla kennara af nemendum. Ætlunin er að draga upp mynd af ólíkri stöðu bóknáms- og starfsnámsbrauta í íslenska framhaldsskólakerfinu út frá fjölbreyttum gögnum og pess vegna er ekki dvalið lengi við hvert atriði. Рað er von höfunda að kortlagningin ýti undir frekari rannsóknir á umfjöllunarefnum greinarinnar.

\section{Skólakerfið próast}

Bóknám í framhaldsskóla vísar til náms sem lengst af hefur pekkst sem nám til stúdentsprófs, hugsað sem áfangi að háskólanámi. Í tímans rás hefur pví verið skipt í ýmsar brautir eđa deildir hér á landi eftir áherslum, fyrst árið 1919 (Kristín Bjarnadóttir, 2007) en pað er alltaf áfangi á lengri leið og samanstendur af bóklegum greinum (pótt t.d. leikfimi og vélritun hafi komið við sögu). Degar á heildina er litið er pað hvorki miðað við sérstakt framhaldsnám né nein sérstök störf, pótt pað hafi framan af einkum verið undirbúningur undir háskólanám fyrir embættismenn og verið að pví marki undirbúningur undir starfsnám (sbr. nám presta, lækna og löglærðra embættismanna). En formlega hefur pað ætíð opnað leið í flestallt háskólanám.

Í fjölpættri uppbyggingu skóla hér á landi á seinni hluta 19. aldar og fram á 20. öld var mikil áhersla lögð á skóla sem menntuðu fólk til starfa, bæði fyrir stúlkur, en pó einkum pilta, og aðsókn að pessum skólum var talsverð alveg frá upphafi. Fjöldi margvíslegra starfsnámsskóla var stofnaður á pessu tímabili og peir döfnuðu vel framan af (Jón Torfi Jónasson, 1998b). Nálægt miðri 20. öld töldu stjórnvöld að of lítið færi fyrir verknámi, p.e. námi sem krefðist einhvers konar handverks, án pess að pað tengdist endilega sérstökum störfum, og töldu jafnframt stöðu starfsnámsgreina of veika. Áhyggjur stjórnvalda verða pó ekki verulegar fyrr en á sjöunda áratug 20. aldar. Í úttekt sinni á menntakerfinu segja matsmenn OECD ,[b]að mjög áberandi í framhaldsskólum hversu háan sess bóknám skipar, og pá sem undirbúningur undir háskólanám“ (Efnahags- og framfarastofnunin, 1987, bls. 22).

Jón Torfi Jónasson (1992) gerir grein fyrir próun framhaldsskólans á 19. og 20. öld frá premur hliðum. Fyrst rökstyður hann pá skoðun að í samhæfingu framhaldsskólastigsins með ýmsum ákvörðunum löggjafans hafi framhaldsskólinn orðið sífellt bóknámsmiðaðri. Í öðru lagi ræðir hann hvað gæti hafa unnið gegn starfsnámsbrautum, ekki síst með pví að skoða á hvaða forsendum stúdentsprófið hafi tekið öll völd (Jón Torfi Jónasson, 1995, 1997). Hann færir rök fyrir pví að öfl sem almennt mætti búast við að stæðu með starfsmenntun í framhaldsskólakerfinu, svo sem atvinnulífið og menntakerfið sjálft, geri pað ekki pegar grannt er skoðað. Hann kallar pau „fjandvini starfsmenntunar”, sem er nokkuð harður dómur (Jón Torfi Jónasson, 1998a). Aðrar hindranir eru óljós staða greina innan kerfisins, blindgötur (raunverulegar eða ímyndaðar) og kostnaðarsamar brautir. Í priðja lagi sýnir hann að próunin á Íslandi hvað varðar vöxt bóknámsbrauta sé sú sama og á öllum Norðurlöndunum pannig að vandinn sem við er að etja er ekki séríslenskur (Jón Torfi Jónasson, 2003). Par leiðir hann líkum að pví að vandinn liggi hugsanlega ekki hjá starfsnámi í sjálfu sér heldur í aðdráttarafli stúdentsprófsins. Detta skiptir máli, pví í umræðu undanfarinna áratuga hefur hlutfallslega minnkandi aðsókn að starfsnámsbrautum oft verið skýrð út frá veikleikum í skipulagi peirra.

\section{Efling starfsnáms}

Ýmislegt hefur verið reynt undanfarna áratugi til pess að jafna stöđu bóknáms- og starfsnámsbrauta og pá er oftast rætt um að efla starfsnám. Fyrsta afdráttarlausa skrefið til pess að styrkja stöðu verknáms (p.e. náms sem átti að leiða til starfsréttinda) var einmitt stigið pegar til stóð að bjóða nemendum upp á val á milli verknáms- og bóknámsdeilda með lögum um gagnfræðaskóla árið 
1946 (lög um gagnfræðanám nr. 48/1946). Markmiðið var að auka fjölbreytni í skólastarfinu og virðingu fyrir verkmenntun og átti breytingin að vera í págu almennrar menntunar, verkmenningar og starfsmenntunar í senn. Í greinargerð með lögunum komu skýrt fram áhyggjur af afstöðu fólks til verknáms, sem hefur verið prástef í umræðu um starfsmenntun, en einnig var rætt um verklega námspætti almennt, eins og sjá má á orðum Gunnars M. Magnússonar:

Takist vel til um verknámskennslu, getur hún veitt proska og menningu engu síður en bóknám. Verknámsdeild ber pví alls ekki að skipa óvirðulegri sess í skólakerfinu en bóknámsdeild og sennilega veitir hún víðtækari rétt að námi loknu. (Gunnar M. Magnússon, 1946, bls. 97)

Matthías Jónasson, prófessor í uppeldisvísindum, taldi að parna væri mögulega stigið framfaraskref til pess að styrkja verkmenningu og virðingu fyrir verknámi (starfsnámi) í landinu. Hann hafði samt talsverðar efasemdir um framvinduna og áhyggjur af viðhorfi fólks:

Framar öllu purfum við að losna undan oki peirrar kreddu, að menntun felist í bóklegum fræðum einum. Verklegt nám er engu síður menntandi ... [og] petta nær ekki tilgangi sínum, nema með pjóðinni vakni sterkur lifandi áhugi á verklegum viðfangsefnum og verklegri menntun. (Matthías Jónasson, 1949, bls. 42-43)

En fyrirhuguð aðgreining náms í fyrstu bekkjum gagnfræðaskólans náði ekki fótfestu og umræða um stöðu starfsmenntunar hefur verið ofarlega á baugi alla tíð síðan og stundum ráðið ferðinni í umræðu um menntamál landsmanna. Fyrir tilstilli Fræðsluráðs Reykjavíkur skrifaði Jóhann S. Hannesson skýrslu um Sameinaðan framhaldsskóla (Fræðsluráð Reykjavíkur, 1971) par sem grunnurinn var lagður að fjölbrautaskólakerfinu. Í skýrslu Jóhanns er augljóslega meginatriðið að gera öllum námsbrautum jafnhátt undir höfði (Jón Torfi Jónasson, 2008b). Рað átti að gera með pví að setja allar námsbrautir undir sama pak og auðvelt átti að vera að flytja sig á milli námsleiða. En pegar til lengri tíma er litið pá dugði pað ekki til. Aðsókn í stúdentsdeildirnar hélt áfram að vaxa, en aðsókn, til dæmis í iðnnám stóð nánast í stað næstu áratugina (Jón Torfi Jónasson, 2008a).

Árið 2006 skipaði menntamálaráðherra nefnd til að takast á við pað verkefni að jafna stöðu bóknáms og starfsnáms. Nefndinni var falið að „kanna hvernig má stuðla að aukinni aðsókn að starfsnámi ... og leggja fram tillögur sem eru til pess fallnar að efla starfsnám til framtíðar“ (Starfsnámsnefnd, 2006, bls. 7). Nefndin gerði mjög afdráttarlausa tillögu um að ,afnumin verði aðgreining náms í framhaldsskólum í starfsnám og bóknám ... námið verði jafngilt" (bls. 3). Dannig mætti hugsa sér að porri nemenda lyki stúdentsprófi frá framhaldsskóla, óhád pví hvort braut væri flokkuð sem bóknáms- eða starfsnámsbraut (bls. 15). Nefndin taldi pví að ekki ætti lengur að tala um bóknámsbrautir sem stúdentsbrautir pví pá væru starfsnámsbrautir ranglega undanskildar.

Í stjórnarsáttmála peirrar ríkisstjórnar sem situr pegar pessi grein er rituð er ákveðið að „¡ðnnám og verk- og starfsnám verður einnig eflt í págu fjölbreytni og öflugra samfélags“" (Stjórnarráđið, 2017, bls. 8). Dannig æetla núverandi stjórnvöld að taka til hendinni, en ásetningur um eflingu starfsnáms hefur verið prástef í opinberri umræðu, eins og hér hefur verið rakið.

\section{Bóknám og starfsnám}

Flokkun námsbrauta hefur verið að breytast og að sumu leyti er hún óljós, eins og notkun hugtaka, bæði í skjölum og umræðu. Í lögum um framhaldsskóla frá 1996 (lög um framhaldsskóla nr. 80/1996) eru námsbrautir flokkaðar sem starfsnám, listnám og bóknám. Enga slíka flokkun er beinlínis að finna í lögunum frá 2008 (lög um framhaldsskóla nr. 92/2008), en hún birtist síðar í aðalnámskránni frá 2011 (Mennta- og menningarmálaráđuneytið, 2012). 
Notkun hugtakanna starfsnám og verknám er gjarnan á reiki. Gestur Guðmundsson (1993) ræðir pessa hugtakanotkun í ítarlegri greiningu á sögu starfsmenntunar í framhaldsskóla mestan hluta 20. aldar og sýnir hvernig pau eru notuð á víxl. En minnt er á að á fyrri tíð hafi bæði verið talað um verknám og iðnnám (sem er vitaskuld starfsnám). Hugtakið verknám hefur pví áđur fyrr verið notað bæði til pess að vísa til einhverrar verklegrar kennslu eða áfanga og einnig til starfsnáms. Raunar er skiptingin nokkuð gömul, einkum að deildir séu kallaðar bóknáms- eða verknámsdeildir, pví af greinargerð með lögum um gagnfræðanám frá 1946, par sem gert er ráð fyrir bóknáms- og verknámsdeild, má ráđa að verknám vísi til verklegra námspátta, en ekki til undirbúnings undir tiltekin störf (Gunnar M. Magnússon, 1946, bls. 97).

Dótt talað sé um starfsnám í lögunum frá 1996 pá er notkun hugtaka óljósari í frumvarpi og greinargerð laganna frá 2008 (Menntamálaráðherra, 2007), en pó virðist verknám ná yfirhöndinni í efnisgreinum par sem starfsnám var notað í frumvarpi og greinargerð laganna frá 1996 (Menntamálaráðherra, 1995).

Hér er hugtakið starfsnám notað frekar en verknám til að undirstrika að á flestum starfsnámsbrautum eru fjölmargir bóklegir áfangar, auk peirra verklegu, og pað kann að vera að pað sem oft er talið bóknám hafi einnig eitthvert verklegt inntak (t.d. efnafræði og jarðfræði). Degar rætt er um starfsnám pá er hér átt við nám á starfsnámsbrautum, eins og gert er í núverandi aðalnámskrá framhaldsskóla (Mennta- og menningarmálaráđuneytið, 2012), nám sem leiðir til einhvers konar starfsréttinda. Skilgreining á bóknámi er hér sömuleiðis tengd notkun hugtaksins bóknámsbraut í aðalnámskrá framhaldsskóla og er vísvitandi ekki formlega tengd stúdentsprófi. Aðalnámskrá gerir nú ráð fyrir að uppistaða náms til stúdentsprófs geti falið í sér hvort sem er nám af bóknáms- eða starfsnámsbrautum. Dess vegna er hér rætt um bóknámsbrautir en ekki stúdentsbrautir og pegar rætt er um einstaka fög eða áfanga sem kenndir eru í framhaldsskólum eru áfangar flokkaðir sem starfsnámsáfangar ef peir tilheyra starfsnámsbrautum og eru ekki hluti af almennum bóknámsgreinum brautar (svo sem félagsvísindi, danska, og náttúruvísindi). En undir almennar bóknámsgreinar falla einnig pær greinar sem kallaðar eru kjarnagreinar í aðalnámskrá (enska, íslenska og stærðfræði).

\section{Rannsóknarspurningar og aðferð}

Markmið greinarinnar er að greina ólíka stöðu bóknáms- og starfsnámsbrauta 1 íslenskum framhaldsskólum og leitað er svara við rannsóknarspurningum sem tengjast hverjum meginkafla.

Í fyrsta meginkafla greiningarinnar er fjallað um hlutverk og áhrif ytri stýringar - pá er sérstaklega vísað til menntastefnu stjórnvalda, til háskólastigsins og til atvinnulífsins - og par er rannsóknarspurningin:

1. Hver er munurinn á stöđu bóknáms- og starfsnámsbrauta í ljósi menntastefnu stjórnvalda, (í lögum um framhaldsskóla, ađalnámskrá framhaldsskóla og námsbrautarlýsingum), háskólastigsins og atvinnulífsins?

Næst er kafli um umgjörð framhaldsskóla og hvað kann að hafa áhrif á val nemenda og par er rannsóknarspurningin:

2. Hvernig hefur umgjörð framhaldsskóla áhrifá skóla- og námsbrautaval? Hver er munurinn á stöđu bóknáms- og starfsnámsbrauta í framhaldsskólunum í pessu ljósi?

Síðasti kaflinn fjallar um fyrirkomulag kennslu og mismunandi afstöðu kennara. Rannsóknarspurningin par er:

3. Hvernig er fyrirkomulagi kennslu á bóknáms- og starfsnámsbrautum í framhaldsskólum háttað og hvernig lýsa kennarar reynslu sinni af nemendum á pessum tveimur flokkum brauta? 
Til að svara pessum spurningum leitum við fanga víða og nýtum okkur ýmsar heimildir og opinber gögn, svo sem lög um framhaldsskóla nr. 92/2008, Aðalnámskrá framhaldsskóla 2011 (Mennta- og menningarmálaráđuneytið, 2012), námsbrautarlýsingar, Hagstofugögn, heimasíður framhaldsskóla, gögn frá Menntamálastofnun og skýrslur frá ráđuneyti menntamála. Við notum einnig jöfnum höndum vettvangslýsingar úr kennslustundum og viðtöl við stjórnendur og kennara úr rannsókninni Starfshættir í framhaldsskólum [1].

Vettvangslýsingarnar byggjast á áhorfi rannsakenda í 130 kennslustundum (sjá Gerði G. Óskarsdóttur og rannsóknarhópinn, 2018). Alls voru 96 stundanna, eða 76\%, kennslustundir á bóknámsbrautum, en par má nefna erlend tungumál, íslensku, stærðfræði, raun- og félagsgreinar, samanborið við 19 stundir, eða 15\%, á starfsnámsbrautum (í fagbóklegum eða verklegum starfsnámsáföngum). Alls voru 15 stundir sem ekki féllu í pessa tvo flokka og eru pær pví ekki teknar hér með. Rannsakendur skráðu framvindu kennslustunda, bæði hvað nemendur og kennarar gerðu og samskipti peirra á milli. Í pessari grein er byggt á flokkun rannsakenda á kennsluaðferðum til að bera saman kennsluaðferðir í bók- og starfsnámi [2].

Tekin voru einstaklingsviðtöl við 21 stjórnanda (skólameistara og millistjórnendur) og 22 kennara. Í úrtakinu voru samtals sex starfsnámskennarar og 16 bóknámskennarar. Viðtölin voru pemagreind (Braun og Clarke, 2006) og var textabrotum safnað saman og pau flokkuð út frá viðfangsefni rannsóknarinnar. Viðtölin við stjórnendur voru pemagreind út frá umræðu um áhrif ytri og innri afla á skipulag náms og kennslu á bóknáms- og starfsnámsbrautum. Viðtöl við kennara voru greind út frá umræðu um kennslu og fjölbreytileika nemendahópsins. Bæði skólar og viðmælendur eru faldir með pví að sleppa nöfnum og mikilvægum auðkennum (Kvale og Brinkmann, 2009).

Heimasíður allra framhaldsskóla voru skoðaðar til að kanna inntökuskilyrði skólanna. Pau textabrot sem við söfnuðum voru pemagreind (Braun og Clarke, 2006) út frá mismunandi inntökuskilyrðum, ólíkri áherslu á einkunnir og eftir skólagerðum, námsbrautum og staðsetningu skólanna. Meginniðurstaða greiningarinnar er sett fram á mynd 1.

Hver kafli fæst við eina rannsóknarspurningu par sem rannsóknargögnum og opinberum gögnum er fléttað saman og niðurstöðurnar ræddar samhliða.

\section{Áhrifmenntastefnu stjórnvalda, háskólastigsins og atvinnulífsins á skipan og starf framhaldsskólanna}

Menntastefna stjórnvalda birtist m.a. í aðalnámskrá og er útfærð nánar í námsbrautarlýsingum framhaldsskóla, sem skulu auglýstar í Stjórnartíðindum (23. gr. laga um framhaldsskóla nr. 92/2008). Dví er mikilvægt að huga að pví hvernig umfjöllun um bóknáms- og starfsnámsbrautir birtist í pessum skjölum. En fleira hefur áhrif á skipan og starf skólanna. Hér verður sérstaklega fjallað um margvísleg bein og óbein áhrif, bæði atvinnulífsins og háskólasamfélagsins.

\section{Menntastefna stjórnvalda: Lög, aðalnámskrár og námsbrautarlýsingar}

Í lögum um framhaldsskóla fær bók- og starfsnám mismikið vægi (lög um framhaldsskóla, nr. 92/2008). Hugtakið bóknám kemur til að mynda aldrei fyrir í lögunum á meðan starfsnám er nefnt sex sinnum og verknám einu sinni. Dá eru bóknámsgreinarnar íslenska, enska og stærðfræði einu námsgreinarnar sem eru nefndar, par sem pessar greinar hafa stöðu kjarnagreina, en vel að merkja, á öllum brautum. Stúdentspróf kemur aftur á móti níu sinnum fyrir í lögunum og er gefið mikið vægi, ,stúdentspróf á bóknáms- og verknámsbrautum [á að vera] jafngilt““ (Menntamálaráðherra, 2007, bls. 19), pannig að hægt sé að fara að pví ólíkar leiðir. 
Háskólastigið fær parna talsvert vægi pví: „Stúdentspróf miðar m.a. að pví markmiði að undirbúa nemendur undir nám á háskólastigi. Við mat á námsbrautarlýsingu til stúdentsprófs og staðfestingu ráðherra á henni skal pað vera tryggt að prófið uppfylli almennar kröfur háskóla um undirbúning fyrir nám á háskólastigi“ (18. gr.).

Atvinnulífið fær samt sem ádur mun skýrara formlegt vægi í gegnum starfsgreinarád, fagráð, starfsgreinanefndir og sveinsprófsnefndir (sbr. 26., 27. og 30. gr.). Í reglugerðum er tilgreind aðkoma aðila atvinnulífsins, sem er breytileg eftir starfsgreinum, en hlutverk peirra er almennt ráðgefandi (sjá t.d. reglugerð um skipan og störf starfsgreinaráða nr. 711/2009). Degar á heildina er litið er umfjöllun um starfsnám og stýringu pess skýrari í lögum og reglum um framhaldsskóla en umfjöllunin um bóknámið.

Námslok á framhaldsskólastigi geta verið framhaldsskólapróf, próf til starfsréttinda, stúdentspróf eða önnur lokapróf og 1 öllum tilvikum (nema prófum til starfsréttinda) geta pessi námslok verið af bóknáms-, listnáms- eða starfsnámsbrautum, m.a. stúdentspróf. Í núgildandi aðalnámskrá framhaldsskóla (Mennta- og menningarmálaráðuneytið, 2012) er greinarmunur á uppbyggingu bóknáms- og starfsnámsbrauta ekki gerður mjög sýnilegur. Til dæmis er tilgreint að á öllum námsbrautum skuli íslenska, enska og stærðfræði vera skylda (í kjarna, bls. 52-53). Megináhersla er lögð á að skilgreina hæfniprep námsloka á námsbrautum. Með hæfniprepum er skilgreint hvaða hæfni nemendur eiga að hafa að námi loknu og par af leiðandi hvaða kröfur eru gerðar til nemenda á tiltekinni námsbraut.

Stúdentspróf hefur pað markmið að undirbúa nemendur undir háskólanám í samræmi við lög um framhaldsskóla nr. 92/2008 (sjá einnig lög um háskóla nr. 63/2006). Námsbraut sem lýkur með stúdentsprófi parf að uppfylla ákveðin skilyrði (Mennta- og menningarmálaráðuneytið, 2012):

1. Námsbraut verður að vera 200 framhaldsskólaeiningar (einingar) að lágmarki (bls. 48) og kjarnagreinar verða að ná að lágmarki 45 einingum.

2. Námslok verða að vera skilgreind á priðja hæfniprepi (bls. 48).

3. Námið er ,alla jafnan skipulagt sem bóknám en getur falið í sér verklegt nám, starfsnám og/eða listnám“ (bls. 87).

Kjarnagreinar (íslenska, stærðfræði og enska) verða að ná að lágmarki 45 einingum. Einnig eru gerðar kröfur, sem eru pó misjafnar eftir brautum, um færni í norrænu tungumáli, priðja tungumáli og samfélags- og raungreinum. Námsbrautir sem leiða til stúdentsprófs geta pví verið ólíkar að inntaki og uppbyggingu.

Próf til starfsréttinda er skilgreint í ađalnámskrá framhaldsskóla (Mennta- og menningarmálaráðuneytið, 2012). Prófinu er ætlað að „veita löggilt starfsréttindi eða gefa nemendum heimild til að preyta sveinspróf í löggildri iðngrein“ (bls. 48). Námslok í starfsnámi geta verið á hæfniprepum tvö til fjögur og segir hæfniprep námsloka til um umfang námsbrautar. Hæfniviðmið í starfsnámi byggjast á hæfnikröfum starfa sem starfsgreinaráð viðkomandi greina tiltekur og á kröfum í aðalnámskrá um lykilhæfni. Gerðar eru kröfur um að nemendur nái hæfni sem samsvari fyrsta hæfniprepi kjarnagreina, en engar frekari kröfur eru settar fram í aðalnámskrá um almennar bóknámsgreinar á starfsnámsbrautum (sem ekki lýkur með stúdentsprófi). Pó var starfsgreinanefnd (2012), að beiðni mennta- og menningarmálaráðuneytisins, fengin til að gefa umsögn um vægi og inntak almennra bóknámsgreina á starfsnámsbrautum. Var niðurstaðan að miða skyldi , ,við pað sem talið er nauðsynlegt með hliðsjón af skilgreindum hæfnikröfum peirra starfa sem mennta skal til“" og ,nemandi á að geta valið um mismikið umfang almennra bóknámsgreina í samræmi við markmið sín og framtíðaráform“.

Hér togast á tvenns konar sjónarmið. Annars vegar er viðleitni í aðalnámskrá til pess að aftengja stúdentspróf og tegund námsbrautar (Mennta- og menningarmálaráđuneytið, 2012). Detta er gert með pví að skilgreina námsbrautir út frá hæfniviðmiðum og prepum, sem er tilraun til að jafna stöðu bóknáms- og starfsnámsbrauta. Hins vegar er uppi hið hefðbundna sjónarmið að 
bóknámsbrautir leiði til stúdentsprófs og áframhaldandi náms í háskóla (lög um framhaldsskóla nr. 92/2008) en starfsnámsbrautir til starfa, par sem kröfur um kjarnagreinar eru gerðar á bóknámsbrautum en ekki starfsnámsbrautum.

Eðlilegt má telja að nemandi á starfsnámsbraut geti valið umfang bóknámsgreina í samræmi við markmið og framtíðaráform, en pað er spurning hversu raunverulegt rými starfsnámsnemendur hafa á sínum námsbrautum til að velja sér umfang bóknámsgreina ef peir hafa á pví áhuga. Samkvæmt „dæmabraut“ mennta- og menningarmálaráđuneytisins hafa nemendur á námsbraut til stúdentsprófs í bóknámi 45-90 einingar (af 200 alls) í frjálst val (Menntamálastofnun, 2018b). Til samanburðar var frjálst val aðeins á premur af peim 30 starfsnámsbrautum sem staðfestar voru pegar petta er skrifað og umfangið var í öllum tilvikum 5 einingar af u.p.b. 200. Hlutfall skyldu (kjarna) á flestum pessara starfsnámsbrauta var yfir $90 \%$ af heildareiningafjölda brautanna. Dessi niðurstaða gefur sterka vísbendingu um hverfandi val á starfsnámsbrautum.

Velta má fyrir sér hvort purfi að gera frekari kröfur um kjarna almennra bóknámsgreina í starfsnámi pegar litið er til pess að í aðalnámskrá kemur fram að námsbrautir á framhaldsskólastigi „,purfa að mæta kröfum atvinnulífs og næsta skólastigs, um leið og pær veita nemendum alhliða almenna menntun“ (Mennta- og menningarmálaráðuneytið, 2012, bls. 7, skáletrun höfunda). Albjóðlega hefur spunnist gagnrýnin umræða um inntak starfsmenntunar, og pá sérstaklega hvað telst til mikilvægrar pekkingar og færni. Gagnrýnin hefur ýmist verið sú að inntak starfsmenntunar sé of almennt eða of sértækt. Umræðan snýst um tilgang menntunar og hvort starfsmenntun á framhaldsskólastigi eigi að pjóna atvinnugrein fyrst og fremst, með áherslu á starfstengda hæfni, eða að auki stefnu yfirvalda um alhliða almenna menntun og pátttöku í lýðræðissamfélagi (sjá t.d. Bernstein, 2000; Hodge, Holford, Milana, Waller og Webb, 2017; Down, Smyth og Robinson, 2017; Wheelahan, 2015). En rannsóknir hafa bent á að ofuráhersla á starfstengda hæfni fyrir tiltekinn vettvang á kostnað almennrar menntunar og lýðræðislegrar umræðuhefðar dragi úr möguleikum starfsnámsnemenda til lýðræðislegrar pátttöku, takmarki aðgengi nemenda að valdastöðum í pjóðfélaginu og viðhaldi stéttaskiptingu (Arnesen og Lundahl, 2006; Nylund o.fl., 2018; Wheelahan, 2007). Ljóst er að pað er ekki yfirlýst markmið aðalnámskrár að viðhalda stéttaskiptingu, en svo virðist sem til grundvallar aðalnámskrá sé pað viðhorf að ekki sé hægt að gera sömu námskröfur til nemenda á starfsnámsbrautum og nemenda á bóknámsbrautum par sem í starfsnámi er lítil áhersla á nám í sumum peirra greina sem teljast vera grunnur alhliða almennrar menntunar. Sennilega er petta viðhorf sprottið af peirri afstöðu að of mikið bóknám á starfsnámsbrautum geti fælt nemendur frá náminu, annaðhvort vegna leiða á bóknámi eða slakari námsfærni í bóknámsgreinum.

Í umræðu um viðmið almennra bóknámsgreina í starfsnámi var vísað í umsögn starfsgreinanefndar (Starfsgreinanefnd, 2012) en við hönnun starfsnámsbrauta á að styðjast við viðmið starfsgreinaráða og óskir atvinnulífsins. Athyglisvert er í pessu samhengi að háskólasamfélagið kemur formlega hvergi nærri viðmiðum um hönnun bóknámsbrauta, pó að markmið peirra sé að búa nemendur undir nám í háskóla. Pó svo að háskólasamfélagið sé ekki tilgreint með sama hætti og starfsgreinarád í peim skjölum sem horft var til má greina akademískar hefðir í aðalnámskrá par sem námsgreinar með aldargamla sögu halda sterkri stöðu sem skilyrði mennta- og menningarmálaráðuneytisins fyrir sampykki bóknámsbrauta og hafa pví forskot á nýrri námsgreinar sem ekki eru nefndar í námskrá. Pær greinar sem halda yfirburðastöðu eru kjarnagreinarnar íslenska, enska og stærðfræði, en einnig Norðurlandamálin, priðja tungumálið, samfélagsgreinar og náttúrufræðigreinar. Aðrar greinar, bóklegar eða verklegar, eru ekki gerðar sýnilegar og staða peirra er pví veikari fyrir bragðið.

Á petta benti stjórnandi í fjölbrautaskóla í viðtali. Фað væri „,búið að gefa pað út að pað séu ákveðnar greinar sem skipti meira máli ... heldur en aðrar ... pessar kjarnagreinar“. Undir petta tók annar stjórnandi sem einnig starfar innan fjölbrautaskólakerfisins og sagði að með pessum hætti hefði „,námskráin ... áhrif ... á sjálfsmynd iðngreina“. Dví er ljóst að aðalnámskrá viðheldur akademískum hefðum með pví að standa vörð um valdamiklar bóknámsgreinar en nefna ekki á nafn nýrri námsgreinar með styttri sögu á sviði starfsnáms eða nýrri bóknámsgreinar. 
Í framhaldi af pessari umræðu mætti spyrja sig hvort einhverjar starfsnámsgreinar ættu heima meðal kjarnagreina bóknámsbrauta í framhaldsskólum.

\section{Stýring háskólastigsins}

Hér að framan hefur verið rökstutt að í formlegri stefnu yfirvalda hafi atvinnulífið meira um starfsnám að segja en háskólinn um bóknám. Sá munur sem birtist í lögunum endurspeglar pó ekki raunverulega stöðu pessara brauta í framhaldsskólum landsins. Stjórnendur framhaldsskólans lýsa umtalsverðum beinum áhrifum háskólastigsins er varða inntak náms, inntökuskilyrði og almenna skólapróun.

Skýrt dæmi um petta er pegar ákveðin fagsvið Háskóla Íslands stýra pví með ýmsu móti hvaða námsgreinar teljast mikilvægar í framhaldsskóla til að nemendum farnist vel eða eigi vísan aðgang að náminu. Sum fagsvið stýra inntökunni með beinum inntökuskilyrðum og krefjast ákveðins fjölda eininga í tilteknum bóknámsgreinum. En á öðrum, til dæmis í laga- og læknadeild, er bein stýring á flæði nemenda á milli skólastiga par sem báðar deildir taka inn nemendur á forsendum inntökuprófa (Háskóli Íslands, 2018a; 2018b; 2018c). Í inntökuprófum ráða sömu kjarnagreinar, íslenska, enska og stærðfræði, og tilgreindar eru í lögum um framhaldsskóla (lög um framhaldsskóla nr. 92/2008) og aðalnámskrá (Mennta- og menningarmálaráđuneytið, 2012). Detta endurspeglast í viðtali við stjórnanda í framhaldsskóla sem bendir á að Háskólinn vill „almennan grunn, ..., læra vinnubrögð og vera góð ... í íslensku, ensku og stærðfræði“.

Framangreindinntökuskilyrði eiga einkumviðáverk-og náttúruvísinda-ogheilbrigðisvísindasviði Háskóla Íslands. Flestum skólastjórnendum sem rætt var við fannst pessi pröngi rammi stýrandi, íhaldssamur og einhliða, eins og kemur fram í máli eins skólastjórnanda: „Svo kemur Háskólinn ... hann parf hérna priðja stig í pessu og annað stig í pessu ... og maður hugsar með sér, já, heyrðu.“ Annar skólastjórnandi tók í sama streng og sagðist ekki vilja „of mikla stýringu“ af hálfu Háskólans. Priðji tók dýpra í árinni og sagði: „,pessar inntökukröfur eða inntökupróf sem háskólinn er að taka upp, sem á að fara að móta og stýra ... mér finnst petta vera algjör blindgata og misskilið“. Háskólarnir, einkum Háskóli Íslands, senda ekki eingöngu skilaboð til framhaldsskólanna um áherslur í gegnum inntökuskilyrði heldur líka með árlegum formlegum fundum með stjórnendum framhaldsskólanna (Guðrún Ragnarsdóttir, 2018).

Háskólastigið stýrir framhaldsskólunum ekki eingöngu með inntökukröfum heldur líka með peirri formlegu menntun sem pað veitir. Framhaldsskólakennarar sem kenna bóknámsgreinar purfa að hafa lokið meistaragrádu og að lágmarki 60 einingum í uppeldis- og kennslufræði (reglugerð um inntak menntunar leik-, grunn- og framhaldsskólakennara nr. 872/2009). Deir kennarar sem kenna lögbundnar iðngreinar purfa að hafa sveinspróf og meistararéttindi í iðngrein ásamt 60 eininga diplómagráđu á grunnstigi til að öðlast kennsluréttindi (lög um menntun og ráðningu kennara og skólastjórnenda við leikskóla, grunnskóla og framhaldsskóla nr. 87/2008). Nám fyrir bóknáms- og starfsnámskennara er pví byggt ólíkt upp pegar horft er til inntaks, námslengdar og námsstigs. Dví er ljóst að ólíkar námskröfur eru gerðar til pessara hópa og námið par með sett á ólíkan stall par sem pað er skipulagt að hluta til á tveimur ólíkum námsstigum innan háskólakerfisins. Um leið er áhugavert að bera saman námslengd kennararéttindanáms hjá peim sem eru með meistaragráđu frá háskóla annars vegar og meistararéttindi í iðngrein hins vegar, en í báðum tilvikum er gerð krafa um 60 eininga kennslufræðinám. Dví má segja að kennslufræðimenntun pessara tveggja hópa sé sambærileg pó að menntun peirra sé á ólíkum skólastigum.

Háskólastigið hefur formleg bein áhrif með lögbundinni menntun bóknámskennara og með tilvísun til pess að námsbrautir til stúdentsprófs séu viðurkenndar af háskólunum, en í reynd pá kemur háskólastigið ekki formlega að sampykkt nýrra námsbrauta. Hvað varðar viðurkenningu námsbrauta pá felst hún í tilteknum aðgangstakmörkunum inn á einstakar námsbrautir háskóla og hins vegar pví að gefa skilaboð til framhaldsskólastigsins um pað hvernig undirbúning nemendur skuli hafa, einkum í íslensku, ensku og stærðfræði. 


\section{Stýring atvinnulífsins}

Í viðtölum við stjórnendur í framhaldsskólum voru áhrif atvinnulífsins einnig rædd. Deir bentu á að stýringin væri ekki eins einstefnuleg og af hálfu háskóla, og lýst var hér að framan. Samstarf framhaldsskólanna við aðila atvinnulífsins virðist að einhverju leyti vera frekar á jafningjagrundvelli en samstarfið við háskólastigið. Dó ber að hafa í huga að stjórnendur töldu að ýmislegt mætti laga í samstarfinu.

Stjórnendur ræddu mikilvægi pess að fá stuðning atvinnulífsins. Til dæmis benti einn skólameistari á að atvinnulífið væri „,mjög styðjandi ... við höfum verið að vinna mjög mikið með atvinnulífinu undanfarin ár ... við höfum verið að kalla eftir samstarfi og stuðningi“. Annar tók í sama streng og benti á að „,sveinsprófsnefndin er með fingurinn á öllu náminu hérna ... peir segja ... petta parf að laga ... peir hjálpa okkur mjög að halda ... kúrsinum í pessu“".

Samt sem áður töldu sumir atvinnulífið oft íhaldssamt, eins og kemur fram í máli eins skólameistara sem benti á að starfsgreinarnar

eru mjög margar... mjög pröngsýnar og lítið fyrir breytingar og lítið fyrir próun ... starfsgreinaráðin sem hugsun er flott sko en ... mannauðurinn er par meira vandamál, heldur en konseptið, ... par eru ... yfirleitt fullorðnir menn sem eru miklir stéttarfélags svona hagsmunamenn ... og bara má engu breyta.

Í sumum tilfellum var stýringu atvinnulífsins lýst sem eins konar gíslatöku par sem pröngir hagsmunir væru varðir. Í pessu samhengi komst einn stjórnandi svo að orði: „,við viljum efla iðnmenntunina en pað eru parna aðilar sem eru kannski líka að gæta ... sinna hagsmuna og eru að tryggja að pað sé ekki of mikil samkeppni inni á markaðinum“. Annar stjórnandi hafði svipaða sögu að segja og taldi pessi hagsmunasamtök verja

sig með kjafti og klóm til að passa upp á að pað séu ekki teknir inn nemar, pað eru settar ... ekki girðingar, heldur bara múrar, völdin liggja í starfsgreinaráðunum ..., pað eru fagfélögin, ... hagsmunir sem að ... geta ekki farið saman.

Hér lýsir viðmælandi pví hvernig atvinnulífið stýrir á vissan hátt flæði nemenda og námsframvindu með pví að tryggja ekki að nemendum sé gert kleift að taka vinnustaðanámshlutann til að geta útskrifast. Sami stjórnandi talaði um hvernig petta viðhorf stæði „frampróun í iðngreinum fyrir prifum“ og taldi að fyrirtækin væru að horfa í „lágu launin“. Dannig töldu sumir stjórnendur framhaldsskólanna að atvinnulífið hefði áhrif á starfsnám nemenda með aðgengi að vinnustaðanámi og launakjörum, sem hvoru tveggja væri á pess könnu. Detta gæeti pýtt að nemendur ættu í sumum tilvikum ekki annarra kosta völ en að hætta námi. Rannsókn Elsu Eiríksdóttur (2017) á samspili náms í skóla og á vinnustað á Íslandi bendir til sömu niðurstöðu, en einnig kom fram að skólarnir gæu verið flöskuháls ef ekki komast allir nemendur par að. Eins hafa atvinnurekendur gagnrýnt skólana fyrir að taka inn fleiri nemendur en atvinnulífið ræður við að pjálfa. Hvað sem öðru líður er ljóst að hér er sýnilegur munur á stöđu bóknámsnemenda og sumra nemenda í starfsnámi. Detta er ekki séríslenskt vandamál. Deng (2013) hefur bent á að námsgreinum sem eiga rætur að rekja til starfs sé stýrt af atvinnulífinu og Wheelahan (2007) bendir jafnframt á stýrandi öfl vinnumarkaðarins í starfsnámi, til dæmis með pví að stjórna fjölda vinnustaðanámssamninga.

Samkvæmt framangreindu skiptum við leiðum atvinnulífs og háskóla til að hafa áhrif á starf framhaldsskólanna í tvo flokka. Annars vegar eru hin formlegu áhrif, sem eru skjalfest í lögum og reglum. Par virðist aðkoma atvinnulífsins vera skýrar tilgreind, t.d. í gegnum starfsgreinaráð sem veita umsögn um námsbrautarlýsingar starfsnámsbrauta framhaldsskóla pegar pær eru sendar til að staðfestingar hjá menntayfirvöldum. Tilgangur umsagnarferlisins er að tryggja samstarf atvinnulífs og skóla og að námsbrautir í starfsnámi séu í samræmi við starfsvettvang, pótt sumir skólameistarar hafi nefnt að pað væri kannski ekki alltaf svo. Óformleg aðkoma atvinnulífsins er mjög fjölpætt, allt frá pví að vinna með einstökum skólum að lifandi próunarstarfi og yfir í tregðu til að leysa úr skorti á samningsplássum í sumum starfsgreinum. 


\section{Áhrif á val nemenda á skóla eða námsbraut}

Að loknum grunnskóla skráir meirihluti nemenda sig á bóknámsbrautir í framhaldsskóla, eða yfir $80 \%$ nemenda. Degar horft er aftur á móti á skráningu allra nemenda í framhaldsskólum eru rúmlega 60\% peirra skráð á bóknámsbraut, sem pýðir að ríflega priðjungur allra framhaldsskólanema stundar nám á starfsnámsbrautum (Mennta- og menningarmálaráđuneytið, 2014; Hagstofa Íslands, 2018b). Dessar tölur gefa til kynna að nemendur skrái sig eldri í starfsnám en í bóknám. Meðalaldur starfsnámsnemenda reynist líka vera 25 ár samanborið við 19 ára meðalaldur bóknámsnema árið 2014 (Mennta- og menningarmálaráðuneytið, 2014). Síðan pá hefur bóknám til stúdentsprófs verið stytt og pví má leiða líkum að pví að munur á međalaldri hafi einungis aukist á milli pessara námsbrautaflokka.

Degar tæplega 3.000 framhaldsskólanemar voru spurðir sögðu aðeins 5-19\% peirra að sér hefði líkað betur að læra bóklegar greinar en verklegar í grunnskóla (Kristjana Stella Blöndal, Jón Torfi Jónasson og Sólrún Sigvaldadóttir, 2016). Eitthvað annað eða fleira en inntak námsgreina virðist pví hafa áhrif á val á námi í framhaldsskóla. Má pví ætla að hér komi kerfislegir, menningarlegir og félagslegir pættir við sögu.

\section{Inntökuskilyrði framha dsskóla}

Framhaldsskólar eru í eðli sínu nokkuð ólíkir og námsframboð peirra er mismunandi. Inntökuskilyrðin í skólana eru mismunandi eftir stöðu og staðsetningu skóla og eðli námsbrauta. Mynd 1 sýnir pennan mun og varpar ljósi á ólíkar áherslur á einkunnir annars vegar og námsgreinar hins vegar og aðrar kröfur sem nefndar eru í inntökuskilyrðum skóla og námsbrautaflokka innan peirra. Skólarnir eru sýndir í ólíkum litum eftir pví hvort um bóknáms- eða starfsnámsbrautir er аð ræða. Peir eru flokkaðir saman til að draga saman megináherslur hvers klasa.

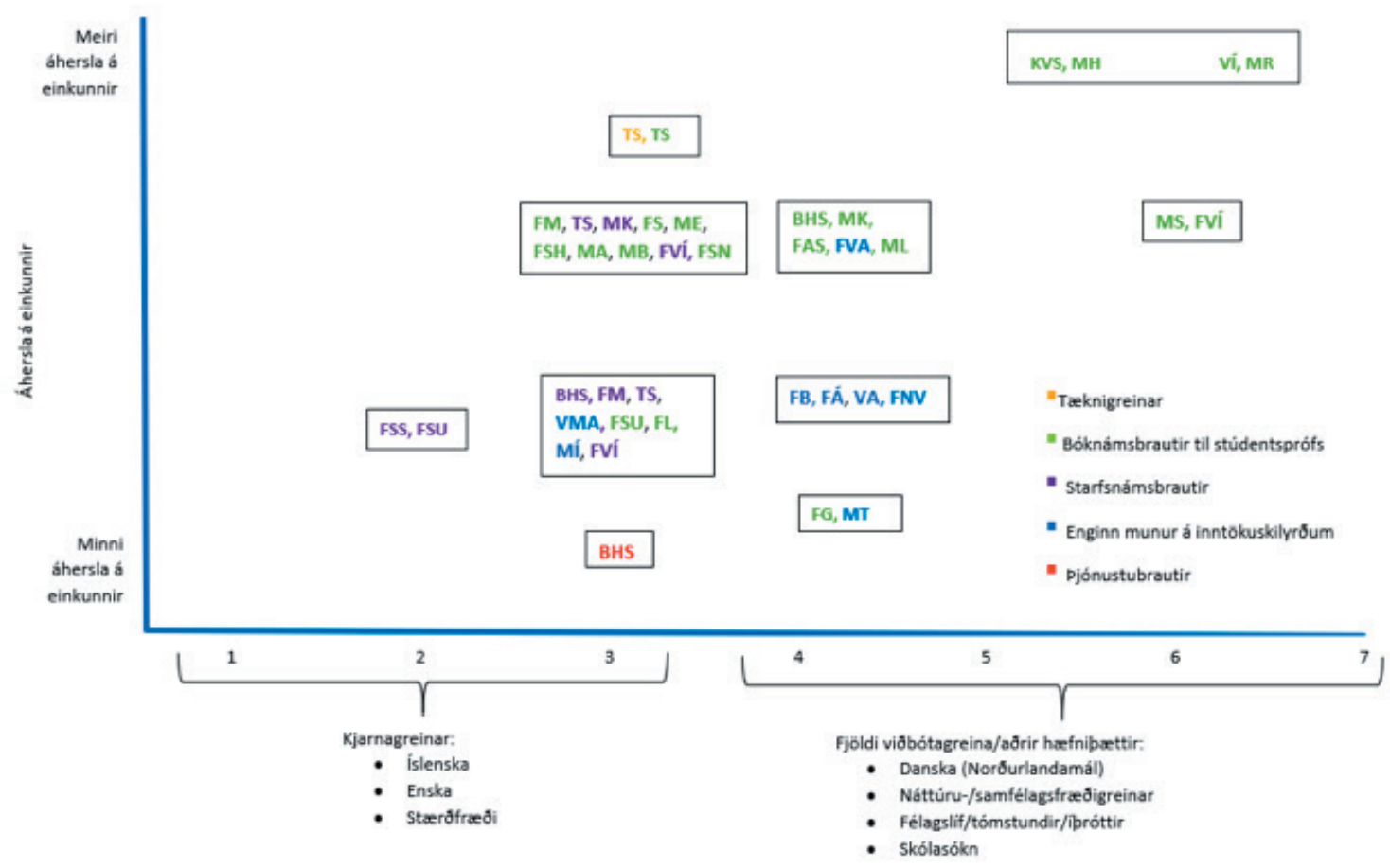

Mynd 1. Kortlagning á inntökuskilyrðum eftir skólum og námsbrautaklösum. Á lárétta ásnum eru sýndar greinar sem tilgreindar eru í inntökuskilyrðum. Á lóðrétta ásnum er gefin til kynna áhersla á einkunnir. Litir sýna til hvað brauta er verið að vísa, pannig að sumir skólar eru sýndir oftar en einu sinni. Á myndinni eru notaðar pekktar skammstafanir framhaldsskóla en aðrar eru: FM - Framhaldsskólinn í Mosfellsbæ, KVS - Kvennaskólinn, MTr - Menntaskólinn á Tröllaskaga og TS - Tækniskólinn. Litir vísa til brautaflokka. 
Almennt eru kjarnagreinarnar íslenska, stærðfræði og enska nefndar sem skilyrði fyrir inntöku inn á námsbrautir framhaldsskólanna. Danska er einnig oft nefnd. Aðeins fjórir skólar (Menntaskólinn við Hamrahlíð, Menntaskólinn í Reykjavík, Kvennaskólinn og Menntaskólinn að Laugarvatni) nefna á heimasíðum sínum annað Norðurlandamál sem jafngildan möguleika. Í einstaka tilvikum er litið til einkunna í raungreinum og samfélagsfræðigreinum og pá helst pegar horft er til inntöku á bóknámsbrautir sem byggjast á bessum námsgreinum. Ađrar námsgreinar eru ekki nefndar sem forsendur fyrir inntöku, sem undirstrikar pað hversu lítið vægi list- og starfsnámsgreinar fá í inntökuferlinu. Tveir skólar (Tækniskólinn og Framhaldsskólinn í Vestmannaeyjum) nefna mætingu í inntökuskilyrðum sínum og tveir (Menntaskólinn í Reykjavík og Verzlunarskóli Íslands) nefna aðra pætti, eins og pátttöku í félagslífi eða ípróttum, stundum einungis til að velja á milli nemenda með jafnháar einkunnir.

Ákveðnir bóknámsskólar á höfuðborgarsvæðinu (Verzlunarskóli Íslands, Kvennaskólinn, Menntaskólinn við Hamrahlíð og Menntaskólinn í Reykjavík) leggja mikla áherslu á að velja nemendur inn eftir einkunnum. Í einhverjum tilvikum er bókstöfum í einkunnakerfi grunnskólanna gefið tölugildi við inntöku og út frá ákveðinni formúlu valdir nemendur með hæstu einkunnirnar í kjarnagreinum. Í einu tilviki er vægi einkunna í stærðfræði og íslensku tvöfaldað í útreikningum.

Degar litið er til fjölbrautaskólanna pá er jafnframt algengt að sjá ólík inntökuskilyrði i bóknámsog starfsnámsbrauta (sjá til dæmis Borgarholtsskóla, Fjölbrautaskóla Suðurlands, Fjölbrautaskóla Suðurnesja og Tækniskólann). Almennt er krafist hærri einkunna inn á bóknámsbrautir til stúdentsprófs en inn á starfsnámsbrautir. Detta er pó ekki algilt. Nokkur dæmi eru um að inn á ákveðnar starfsnámsbrautir sé krafist jafnhárra einkunna í kjarnagreinum og jafnvel hærri einkunna en krafist er inn á náttúrufræðibrautir í sama skóla (sjá Tækniskólann), en almennt er hærri einkunna krafist til inntöku á náttúrufræðibrautir en á aðrar bóknámsbrautir.

Á sumum starfsnámsbrautum eru íslenska og stærðfræði einu námsgreinarnar sem nefndar eru í inntökuskilyrðum og áherslan á einkunnir er almennt lítil (sjá til dæmis Fjölbrautaskóla Suðurlands og Fjölbrautaskóla Suðurnesja). En einnig má sjá ólíka stöðu starfsnámsbrauta innan sama skóla par sem hærri einkunnir eru oft inntökuskilyrði inn á starfsnámsbrautir sem hafa hærri stöðu í samfélaginu, eins og til dæmis tæknibrautir eða löggiltar iðngreinar (sjá Tækniskólann). Í sumum tilfellum virðast inntökuskilyrði vera rýmri inn á starfsnámsbrautir sem fást við „mýkri“ málefni eins og umönnun (sjá Borgarholtsskóla).

Einstaka skólar gera ekki greinarmun á bóknáms- og starfsnámsbrautum, og hafa t.d. inntökuskilyrðin pau sömu fyrir allar brautir sem lýkur með stúdentsprófi, og enn aðrir taka pað sérstaklega fram að öllum nemendum sé velkomið að stunda nám í skólanum: „Allir sem hafa áhuga á framhaldsskólanámi eru velkomnir“ (Menntaskólinn á Ísafirði, e.d.). Betta á einkum við um framhaldsskóla á landsbyggðinni. Almennt er meiri áhersla lögð á háar einkunnir á höfuðborgarsvæðinu en á landsbyggðinni og pað gefur vísbendingu um erfiða samkeppnisstöðu framhaldsskóla í smærri byggðum. Í pessu sambandi má nefna að í viðtali benti skólastjórnandi á höfuðborgarsvæðinu á pá samkeppni sem á sér stað pegar kemur að inntökunni og sagði hana vera háda

tísku, ... pað er bara ... menntamarkaður í gangi, skólar fara í tísku, úr tísku og við sjáum alveg að fjölmiðlar móta líka pá sýn, hverjir, hvaða skólar fara í tísku ... pessi skilaboð koma auðvitað frá samfélaginu, pau koma líka hérna frá námsráđgjöfum í grunnskólunum, peir eru mjög markandi hvert pau fara.

Athygli skal vakin á pví að almennt er ekki horft til fjölbreyttrar hæfni nemenda við inntöku á ólíkar námsbrautir, heldur er nánast eingöngu tekið mið af bóknámsgreinum við inntökuna. Niðurstöðurnar sýna ólíka áherslu á einkunnir pegar horft er til inntökuskilyrða framhaldsskólanna. Detta endurspeglast í mismunandi virðinga- og samkeppnisstöðu skólanna, sem meðal annars ræðst af skólagerðum, námsframboði, landfræðilegri staðsetningu, hefðum og sögu peirra. En pað eru ekki bara inntökuskilyrði sem hafa áhrif á námsval nemenda heldur líka foreldrar, búseta og kyn. 


\section{Áhrif foreldra, búsetu og kyns á val nemenda}

Foreldrar og samfélagið prýsta á nemendur að halda öllum tækifærum opnum með pví að halda að peim námi til stúdentsprófs, og pá helst á bóknámsbrautum. Detta kom skýrt fram í viðtölum við skólastjórnendur, sem bentu á að almennt stýrðu foreldrar börnum sínum með kerfisbundnum hætti í bóknám til stúdentsprófs, og pá gjarnan í bekkjarskóla með langa sögu og sterka samfélagslega stöðu, í stað starfsnáms eða jafnvel bóknámsbrautar í fjölbrautaskóla.

Einn stjórnandi í bóknámsskóla benti á pá tilhneigingu að nemendur færu sömu leið og foreldrar peirra gerðu í gegnum bóknám, hann sagði pað vera ,ríka hefð, pabbi og mamma voru í [nafn framhaldsskóla]“. Annar skólastjórnandi í fjölbrautaskóla samsinnti og sagði:

Рað er lenska að barnið mitt á að fara sömu leið og ég. Рað á að fara í bóknám og pá fer pað náttúrulega í menntaskóla ... pú ert að hvetja barnið til pess að mennta sig pannig að pað fari í burtu úr bænum.

Dví er ljóst að bóknámshefðin er sterk og áhrif foreldra mikil. Dessi áhersla á bóknám kemur einnig fram pegar rætt er um möguleikann að velja starfsnámsbrautir. Stjórnandi í fjölbrautarskóla benti á að foreldrar ,segja við börnin sín að pau eigi fyrst að taka stúdentspróf áđur en pau læri verknám ... ofurtrúin er á stúdentsprófið“. Skólastjórnandi í öðrum fjölbrautaskóla samsinnti pessu og sagði langflesta foreldra „vilja að börnin peirra taki stúdentspróf“.

Af pessu má ráđa að foreldrar bera mikið traust til bóknámsbrauta til stúdentsprófs og leitast pannig við að tryggja börnum sínum „,besta“ mögulega undirbúning fyrir háskólanám. Petta gera foreldrar jafnvel pótt barnið peirra gæeti haft áhuga á öðru námi. Dað er í samræmi við niðurstöður Kristjönu Stellu Blöndal o.fl. (2016). Dau benda á að meirihluti framhaldsskólanemenda (85\%) telur foreldra sína fyrst og fremst vilja að pau ljúki námi til stúdentsprófs og fimmtungur segir foreldra sína leggja meiri áherslu en pau sjálf á að ljúka stúdentsprófi. Að auki sagði meirihluti (78\%) nemenda á bóknámsbrautum að foreldrar peirra hefðu væntingar um að pau legðu stund á háskólanám í framhaldi, samanborið við 40\% starfsnámsnema. Erlendar rannsóknir hafa sýnt fram á svipaðar niðurstöður og að foreldrar telji hefðbundið akademískt bóknám besta undirbúninginn fyrir framtíð barna sinna (Braun, Ball, Maguire og Hoskins, 2011). Dessi gildi endurspegla svo hefðaveldi náms par sem bóknám, sem opnar leið inn á háskólastig, stendur ofar í stigveldinu en starfsnám (Bleazby, 2015), sem gerir pað ekki endilega.

En aðrir pættir en afstaða foreldra hafa einnig áhrif á valkosti nemenda og búseta er einn peirra. pröstur Pór Ólafsson (2017) skoðaði í rannsókn sinni póstnúmer lögheimila framhaldsskólanema í starfsnámi á landsbyggðinni. Par sýnir hann fram á að par sem bóknámsskólar voru í heimabyggð voru nemendur ólíklegri til að velja starfsnám. Pannig virtust neme ndur sem gátu valið bóknám í heimabyggð velja pað frekar en að sækja lengra í starfsnám, sérstaklega strax eftir grunnskólanám. Ef horft er til pess að allir framhaldsskólar sem settir hafa verið á fót frá árinu 2000 eru bóknámsskólar, og að sérstök áhersla hefur verið á stofnun framhaldsskóla á landsbyggðinni, virðist nemendum á landsbyggðinni stýrt í ríkari mæli í bóknám en áđur var.

Hið sama kom fram í viðtölum við skólastjórnendur framhaldsskóla á landsbyggðinni, en peim var tíðrætt um jafnrétti til náms og pá sérstaklega út frá ólíkri stöđu bók- og starfsnáms. Einn skólastjórnandi í fjölbrautaskóla á landsbyggðinni benti á að pau væru

að reyna að pjóna nærsamfélaginu, við erum ekkert síður að mennta nemendur til pess að geta farið í störf hér á svæðinu, að [peir] geti haldið áfram að búa hérna og pá erum við ekkert síður að leggja áherslu á tækninámið eins og petta bóknám ... pað er svolítið galli að pað fer eftir pví hvar pú býrð á landinu hvaða möguleika pú hefur til náms, pað fer eftir pví hvar á landinu pú býrð hvort pú getir yfirhöfuð farið í verknám.

Í pessu sambandi benti annar stjórnandi utan höfuðborgarsvæðisins á að ef nemendur ætla sér í starfsnám eftir 10. bekk ,„pá verðurðu að fara strax að heiman pví annars ertu að eyða einu 
tveimur árum í heimabyggð í bóknámi sem gagnast pér ... ekki“. Annar skólastjórnandi af landsbyggðinni sagði byggðapróunina vera helstu ógnina og að nemendur sem ætluðu sér að „fara í starfsnám, peir fara héðan“. Hér er rétt að benda á hversu erfitt getur verið að bjóða upp á mikið úrval námsbrauta í litlum skólum. Eins og einn skólameistari á landsbyggðinni benti á pá er staðan erfið í smærri byggðum par sem markaðurinn mettast fljótt og nemendafæð gerir skólunum erfitt fyrir að bjóða upp á mikið val um námsbrautir.

Dað er samdóma álit peirra skólastjórnenda sem leiða litla skóla á landsbyggðinni að pessir skólar gegni mikilvægu hlutverki í byggðapróun og að jafna tækifæri til náms. Einn benti á að skólinn á svæðinu væri

til fyrir samfélagið, til pess að pjónusta samfélagið og parf að svara peim pörfum sem að eru í samfélaginu ... pá er hann [skólinn] ... til fyrir nemendur og nemendur geta verið áfram í sinni heimabyggð ... eins heldur hann uppi menntunarstigi, petta er stór vinnustaður.

Félagslegt réttlæti er mikilvægt sjónarmið og pað skiptir máli fyrir nemendur að geta verið lengur heima, bæði par sem nú pykir snemmt fyrir 16 ára ungmenni að flytja að heiman auk pess sem kostnaður fylgir flutningum fyrir fjölskyldur.

Að lokum má nefna að víða gætir mikils kynjahalla í starfsgreinum. Árið 2014 voru yfir 70\% nemenda af sama kyni í 30 af 39 iðngreinum (Hagstofa Íslands, 2018b). Í flestum, eða 26, voru karlmenn í meirihluta, og voru karlmenn yfir 90\% nemenda í 19 iðngreinum (t.d. í bifreiðasmíði, húsasmíði og rafvirkjun). Aðeins á sex námsbrautum iðngreina voru konur í meirihluta, og voru yfir 90\% nemenda konur á fimm peirra (t.d. í hársnyrtiiðn, bókbandi og klæðskurði). Einungis á sjö námsbrautum iðngreina var kynjahlutfallið jafnara, eða á bilinu 30-70\% (t.d. í framreiðslu, húsgagnasmíði og grafískri miðlun). Ef annað starfsnám en iðnnám er skoðað kemur í ljós að á starfsnámsbrautum í pjónustugreinum (félagsliðar, skólaliðar og stuðningsfulltrúar) eru konur sem sækja námið yfir 80\% og í heilbrigðisgreinum (læknaritarar, sjúkraliðar og tanntæknar) eru konur einnig í meirihluta.

Dað er pví ljóst að starfsnám fylgir mjög hefðbundinni kynjaskiptingu par sem konur eru í umönnunar- og pjónustugreinum á meðan karlar eru í byggingar- og tæknigreinum. Sú mynd sem birtist af fagfólki í starfsgreinum er sennilega misaðlaðandi fyrir nemendur pegar horft er til kyns. Leiða má líkum að pví að nemendur séu ekki tilbúnir, við 16 ára aldur, að ganga gegn hefðbundnu kynjakerfi og menningu í starfsnámi. Dví er líklegt að kynjahlutfall starfsgreina sé einnig áhrifapáttur í vali nemenda á námi í framhaldsskólum.

\section{Lengd og sérhæfing námsbrauta}

Almennt er miðað við að nemendur ljúki námi til stúdentsprófs á um premur árum. Einnig er kveðið á um að eitt námsár sé ársvinna nemanda og jafngildi 60 einingum (lög um framhaldsskóla nr. 92/2008, 15. gr.). Detta pýðir að pað ætti að taka nemendur sjö annir að ljúka námi til stúdentsprófs, sem er að lágmarki 200 einingar (Mennta- og menningarmálaráduneytið, 2012). Dví virðist ársvinna nemenda í raun jafngilda meira en 60 einingum.

Sett eru önnur skilyrði um lengd starfsnáms í einingum talið, enda geta starfsnámsbrautir verið mjög ólíkar innbyrðis og að auki er vinnustaðanám innbyggt í námsbrautarlýsingar starfsnáms (Menntamálastofnun, 2018b). Hámarkseiningafjöldi er 300 einingar, en gert er ráð fyrir að námið sé aldrei lengra en fjögur ár (Steingrímur A. Jónsson, munnleg heimild, 8.5.2018). Í peim tilfellum er gert ráð fyrir pví að nám á vinnustað geti farið fram utan hefðbundins skólaárs. Af peim 30 starfsnámsbrautum sem hafa verið staðfestar af ráðherra pegar petta er skrifað og ná námslokum á priðja hæfniprepi (eins og stúdentspróf) eru flestar að lágmarki 200 einingar og að meðaltali purfa starfsnámsnemendur að ljúka 231 einingu til að brautskrást. Yfirleitt eru starfsnámsbrautir með námslok á priðja hæfniprepi pví jafnlangar eða lengri en bóknámsbrautir. 
Flestar starfsnámsbrautir veita nemendum ekki aðgang að háskólanámi nema að undangengnum bóknámsgreinakjarna sem pessir nemendur sækja sér oft með viðbótarnámi til stúdentsprófs (Menntamálastofnun, 2018b). Detta viðbótarnám getur verið allt að 55 einingar og bætir pá einu námsári við priggja til fjögurra ára starfsnám. Í einhverjum tilvikum er starfsnámsbraut skilgreind til stúdentsprófs, en pað heyrir til undantekninga. Nemandi sem vill bæði ljúka starfsnámi og stúdentsprófi getur pví purft að vera tveimur árum lengur í námi en nemandi á bóknámsbraut.

Degar rætt er um eflingu starfsnáms er oft bent á pad hversu lágt hlutfall nemenda velur sér starfsnám að loknum grunnskóla, en mikilvægt er að huga að pví hvort nemendur séu í raun tilbúnir til að velja sér starfsvettvang til framtíðar við 16 ára aldur. Ekki síst á petta við pegar valið felur í sér lengra nám, takmarkaðri möguleika á framhaldsnámi og í sumum tilvikum óvissu um námssamning. Đó að starfsnám sé ekki öngstræti í menntakerfinu eru svo ungir nemendur ekki endilega tilbúnir til að skuldbinda sig starfsgrein, sérstaklega par sem starfsnámið tekur lengri tíma og pað er meiri fyrirhöfn að halda flestum möguleikum opnum.

Pannig má spyrja sig hversu aðlaðandi starfsnámsbrautir eru fyrir nemendur, sem kannski hafa áhuga á starfsnámi en eru ekki að fullu ákveðnir, vegna pess hve mikil sérhæfing felst í náminu í samanburði við bóknámsbrautir. Nemendur sem skipta um skoðun eigi pað pví á hættu að fá lítið metið inn á aðrar námsbrautir, sem aftur getur valdið töfum á námi. Darf pví engan að undra að starfsnámsnemendur eru almennt vissari um námsval sitt en nemendur í bóknámi (Kristjana Stella Blöndal o.fl., 2016). Ef nemandi er ekki fullviss um áhuga á framtíðarstarfi og sækist eftir að halda sem flestum möguleikum opnum er ekki undarlegt að bóknámsbraut verði frekar fyrir valinu, einkum ef áhersla samfélagsins er sömuleiðis á bóknámsbrautir til stúdentsprófs. Detta gæti að einhverju leyti útskýrt hærri meðalaldur starfsnámsnema en bóknámsnema: Fólk velur starfsnám pegar pað er orðið eldra og vissara um val sitt og framtíðaráform.

Brotthvarf er meira úr starfsnámi en bóknámi og í Hvítbók um umbætur í menntun (Mennta- og menningarmálaráðuneytið, 2014) kemur fram að vorið 2013 höfðu um 55\% nemenda í starfsnámi ekki lokið námi að loknum sex árum í framhaldsskóla, en sambærileg tala fyrir bóknám var um 22\%. Í pessu sambandi má velta pví upp hvort starfsnám geri meiri kröfur til proska og skuldbindingar til náms en bóknám. Nemendur purfa ekki bara að sérhæfa sig meira, heldur purfa peir einnig að útvega sér samning vegna náms á vinnustað og taka pátt í samfélagi fullorðinna. Í löggiltum iðngreinum er pað á ábyrgð nemandans að komast á samning og skipuleggja samspil náms í skóla og vinnustaðar (Elsa Eiríksdóttir, 2017). Erfiðleikar við að finna vinnuveitanda sem er tilbúinn til að taka nema í pjálfun hafa ugglaust áhrif á brotthvarf. Slík staða er ekki fyrir hendi á bóknámsbraut, sem sýnir mikinn stöðumun bók- og starfsnáms.

\section{Fyrirkomulag kennslu í framhaldsskólum og viðhorf kennara}

Rannsóknin á starfsháttum í framhaldsskólum gefur vísbendingar um pað hvernig kennslu í framhaldsskólum er háttað í bóknámi og starfsnámi. Hér á eftir eru upplýsingar um kennslustundir teknar saman á grundvelli vettvangslýsinga. Einnig er greint frá reynslu bóknáms- og starfsnámskennara af nemendum.

\section{Kennslustundir á bóknáms- og starfsnámsbrautum}

Samanburðurá kennslustundum áfanga á bóknáms- og starfsnámsbrautum sýndi að kennslustundir í bóknámi voru marktækt styttri $(\mathrm{M}=68 \mathrm{mín}$, sf $=26)$ en kennslustundir í starfsnámi $(\mathrm{M}=$ 102 mín, sf $=58 ; \mathrm{t}(113)=-4,13, \mathrm{p}<0,05)$. Dessar niðurstöður sýna að brautirnar gera ólíkar kröfur um skipulag. Starfsnámsáfangar taka almennt lengri samfelldan tíma yfir daginn par sem nemendur purfa lengri tíma til að takast á við verkleg verkefni og erfitt getur verið að hætta í miðjum klíðum. En einnig fer mikill tími í pað að finna til og taka saman verkfæri. Kennarar og nemendur hittast hins vegar oftar yfir vikuna í styttri tíma í senn í bóknámsáföngum. Eðli máls samkvæmt er oft krefjandi í stundatöflugerð að skipuleggja saman kennslustundir í bók- og starfsnámi. 
Skoðaðar voru pær kennsluaðferðir sem beitt varí kennslustundum bóknáms- og starfsnámsáfanga. Kennsluaðferðir í 112 kennslustundum voru flokkaðar í sex flokka og eru niðurstöður sýndar í töflu 1.

Tafla 1. Taflan sýnir hlutfall kennslustunda innan sex flokka kennsluaðferða sem beitt var í kennslustundum bóknámsbrauta (96 kennslustundir) og starfsnámsbrauta (19 kennslustundir). Oft voru notaðar fleiri en ein kennsluaðferð í einni kennslustund.

\begin{tabular}{lcccccc}
\hline $\begin{array}{l}\text { Tegund } \\
\text { kennslu- } \\
\text { stundar }\end{array}$ & $\begin{array}{c}\text { Bein kennsla } \\
\text { (fyrirlestur, } \\
\text { sýnikennsla) }\end{array}$ & $\begin{array}{c}\text { Gagnvirk miðlun } \\
\text { (spurningar til } \\
\text { nemenda) }\end{array}$ & Umræður & $\begin{array}{c}\text { Einstaklings- } \\
\text { verkefni }\end{array}$ & $\begin{array}{c}\text { Valfrjáls } \\
\text { samvinna }\end{array}$ & $\begin{array}{c}\text { Hóp- } \\
\text { verkefni }\end{array}$ \\
\hline $\begin{array}{l}\text { Bóknáms- } \\
\text { brautir }\end{array}$ & $39 \%$ & $36 \%$ & $2 \%$ & $55 \%$ & $10 \%$ & $40 \%$ \\
$\begin{array}{l}\text { Starfsnáms- } \\
\text { brautir }\end{array}$ & $42 \%$ & $32 \%$ & $5 \%$ & $63 \%$ & $16 \%$ & $16 \%$ \\
\hline
\end{tabular}

Aðeins í einum flokki kennsluaðferða birtist áberandi munur. Í bóknámsáföngum virðist vera meira um hópverkefni en í starfsnámsáföngum, en pó er ástæða til að ætla að hópa- eða samvinna nemenda sé ekki síður mikilvæg í starfsnámi par sem ýmis framtíðarviðfangsefni starfsnámsnema feli í sér samvinnu, eins og lögð er t.d. áhersla á í lausnaleitarnámi. Að auki koma oft upp fjölmörg álitamál í starfsnámi er varða öryggismál, samskipti og náttúruvernd. Slík viðfangsefni falla vel að hópavinnu. Dví er athyglisvert hversu hópverkefni eru tiltölulega lítið notuð með kerfisbundnum hætti á starfsnámsbrautum.

Kennari gengur oftast á milli og aðstoðar nemendur eftir pörfum í bóknámsgreinum á meðan nemendur vinna á sínum hraða að einstaklingsverkefnum í starfsnámi (Elsa Eiríksdóttir og Rosvall, 2018). Fyrirkomulagið innan bóknámsgreina er almennt fjölbreyttara en innan starfsnámsgreina en pó sýna rannsóknir á kennsluaðferðum (Ingvar Sigurgeirsson, Ingólfur Ásgeir Jóhannesson og Elsa Eiríksdóttir, 2018) að innan svipaðra námsgreina og námsgreinaflokka í bóknámi geta kennsluhættir oft verið æði einsleitir.

\section{Reynsla framhaldsskólakennara af kennslu ólíkra nemendahópa}

Fjölbreytileiki nemendahópsins á starfsnámsbrautum er starfsnámskennurum ofarlega í huga. Einn kennari ræddi getubreidd nemenda: „Já við erum með, já ... mjög stóra flóru [nemenda, sem nær frá] ... afburðanemendum og ... [til peirra] sem að eiga mjög erfitt með nám.“ Einnig var talað um hátt hlutfall nemenda með einhverja námsörðugleika: ,sem er kannski líka svolítið slæmt, við erum með mikið af, má segja, lesblindir og allar pessar [greiningar], ADHD og pess háttar,“ og annar sagði: „ætli ég geti ekki sagt 70-80\% nemenda hjá okkur eru með einhverja greiningu ... pað sé stærsti hópurinn sem eru með lesblindu og svo bara ýmsir námserfiðleikar, ofvirkni“. Deir útskýrðu pennan breytileika í nemendahópnum meðal annars með vísun til pess að stærri hluti hvers árgangs hefur nám í framhaldsskóla nú en ádur:

Deir nemendur sem við vorum að fá úr grunnskóla, voru svona peir sem að áttu erfiðara með bóknám, pannig að við erum að fá dálítið af nemendum ... sem að hér á árum áđur fóru ekkert meira í skóla ... nú eru allir að fara í nám.

En einnig birtist breidd nemendahópsins í aldursdreifingu, eins og einn starfsnámskennari lýsti: „frá 17 ára og upp í prítugt“. Starfsnámskennarar fá pví gjarnan til sín eldri nemendur sem hefja nám pegar peir hafa áttað sig á pví hvað peir vilja gera. Detta eru oft nemendur með lífsreynslu sem hafa áhuga á faginu og pess vegna meiri drifkraft. Annar starfsnámskennari ræddi hvernig pessir eldri nemendur væru oft sterkari námsmenn: 
Núna bara síðustu árin erum við samt að fá mjög sterka nemendur, sem sagt, pá eldri nemendur, nemendur jafnvel sem eru búnir að fara í háskólann, bara eins og einn sagði núna bara á pessari önn ..., ,ég fór í háskólann fyrir mömmu, en nú er ég farinn að læra fyrir mig.

En einnig töluðu peir um fullorðna námsmenn, sem kæmu aftur í nám eftir að hafa horfið frá námi og oft með brotna skólasögu:

Sumir nemendur sem eru brenndir af skólakerfinu, peir eru að koma inn aftur, peim gekk ekki vel í skóla ... fengu eitthvað neikvætt viðhorf ... en pað er töluvert um pað í mörgum iðngreinum að peir eru að koma núna og eru að spreyta sig og margir hverjir bara standa sig alveg með prýði og eru hissa á pví.

Sumir starfsnámskennaranna ræddu mikilvægi pess að nálgast pessa nemendur og byggja námið pannig upp að peir næðu árangri. Nokkrir viðmælendur sögðu að nemendum sem erfitt ættu með bóknám væri gjarnan vísað í starfsnám. Einnig bentu peir á að margir nemendur fyndu sig frekar í verklegu greinunum en bóklegum:

Detta eru einstaklingar sem eru klárir að vinna með höndunum ... pau standa sig ofsalega vel í pessu verklega, en pau taka út fyrir að vera í pessu bóklega, ... peim finnst pað vera óparfi, pau purfa ekki, til hvers parf ég að vera í pessu bóklega, ég kann petta verklega, og pað sé bara nóg.

Fjölbreyttur nemendahópur var stef í máli starfsnámskennara og bentu nokkrir á að pað væri töluverð áskorun að takast á við kennslu pegar breytileikinn er svo mikill.

Bóknámskennarar fjölluðu með allt öðrum hætti um nemendahópinn. Flestir töluðu um breidd nemendahópsins út frá getu í peirri faggrein sem peir kenndu, til dæmis mismunandi stöðu nemenda í íslensku, stærðfræði eða ensku, frekar en út frá almennri hæfni eins og starfsnámskennararnir. Einn kennari sagði:

Detta eru bara finir krakkar, pau eru ofboðslega mismunandi getulega séð ... sum koma með pokkalegan grunn úr grunnskóla, sum koma með nánast engan grunn ... börn sem hafa kannski verið að ná 4,5 og kannski flotið áfram á vinum í hópaverkefnum og eitthvað svoleiðis, önnur eru bara, standa sig vel og eru bara toppar inni í sínum hóp.

Рað er pó áberandi að munur er á tali bóknámskennara eftir pví í hvernig framhaldsskóla peir starfa. Í tveimur bekkjarskólunum töluðu viðmælendur um að skólinn veldi inn nemendur eftir einkunnum og pví væri ekki mikil breidd í nemendahópnum: „Баð er tekið inn eftir einkunnum ... pannig að við erum nú með tiltölulega góða nemendur, yfir heildina“ og annar kennari ber skólann saman við aðra skóla: „Ég er alveg handviss um pað að við erum náttúrulega ekki með jafnbreiðan hóp og ýmsir aðrir skólar.“ Dessir kennarar töluðu ekki um áskoranir vegna námsörðugleika eða getu, heldur frekar vegna vinnu nemenda með skóla, og um áhugahvöt og virkni. Bóknámskennarar í tveimur fjölbrautaskólum ræddu aftur á móti um mikinn fjölbreytileika í nemendahópnum:

Hópurinn okkar hefur verið rosalega fjölbreyttur. Og við höfum líka verið ... með óvenju hátt hlutfall af greiningum, og öðru slíku, sem að hefur áhrif á hópinn. En ég sé ekki pað sem fyrirstöðu. Mér finnst pað bara frábært, hérna, pví fjölbreyttara pví betra, í hópnum. Vegna pess að pú færð hérna allt öðruvísi vinnu pegar pú ert með svona fjölbreyttan hóp. Đá finnurðu styrkleikann hjá nemendunum og pú reynir að hafa sem fjölbreyttast pannig að allir geti komist áfram. En brottfallið er hátt og ég held að pað sé líka af pví að ... pau sjá allt í einu að ... pú veist, ég get ekki skilað .... Pá hverfur maður.

Einnig ræddu pessir sömu bóknámskennarar um eldri nemendur og útskýrðu breidd nemendahópsins með vísun til fjölda endurkomunemenda og nemenda sem skipt höfðu um 
skóla. Dessir bóknámskennarar lýstu pví svipaðri reynslu og starfsnámskennararnir gerðu hér að framan og fjölluðu um pær áskoranir sem fylgja pví að kenna svona fjölbreyttum hópi nemenda.

Aðrir bóknámskennarar ræddu pó einnig um glímuna við að koma til móts við nemendur sem gengi illa og væru í brotthvarfshættu. En einnig lýstu peir erfiðleikum við pað að virkja nemendur og vekja áhuga peirra. Einn bóknámskennari tók sérstaklega fram að nemendur veldu oft ekki eftir áhuga. Deir væru

að drepast úr leiðindum og eru pau bara að detta út pess vegna, af pví pað er ekki tekið eftir peim, bekkirnir eru orðnir svona stórir og peir hverfa bara inn í fjöldann ... eru pau bara öll send ... eitthvað bóknám sem pau hafa engan áhuga á og myndu blómstra einhverstaðar annars staðar ... eru fleiri sem ættu heima kannski í iðngreinunum.

En í umræðu um brotthvarf og val á námi kom einnig á daginn að starfsnám gæeti reynst nemendum erfiðara en oft er ætlað, eins og einn starfsnámskennari sagði um nemendur sem hverfa frá starfsnámi á fyrsta ári:

Já, ég veit að peir fara inn á stúdentsnámsbrautir, margir. Pað eru peir sem falla bara, eru ekkert svona iðnaðarmenn í sér og mér finnst alltaf voðalega gaman pegar maður fer á útskrift og sér-já pessi byrjaði i [starfsnáms] deild og féll og fór svo bara á náttúrufræđibraut.

Reynsla framhaldsskólakennara af nemendahópnum sem peir kenna virðist pví ólík eftir pví hvort peir kenna nemendum á starfsnáms- eða bóknámsbrautum. Starfsnámskennarar virðast fást við töluvert fjölbreyttari nemendahóp en bóknámskennarar, og pá sérstaklega peir sem kenna við skóla með strangari inntökuskilyrði.

\section{Að lokum}

Ljóst er að pversagnir og kerfisvillur eru vel sýnilegar í íslensku skólakerfi og birtast meðal annars í stöđumun bóknámsbrauta annars vegar og starfsnámsbrauta hins vegar. Pegar horft er frá peim premur sjónarhornum sem kynnt hafa verið í greininni, (1) hlutverki og áhrifum ytri stýringar, (2) umgjörð framhaldsskóla og áhrifum á val nemenda og (3) fyrirkomulagi kennslu og reynslu kennara, er ljóst að staða pessara tveggja flokka námsbrauta er ólík í öllum tilvikum.

Bóknámshefðir og reglur tengdar peim eru ráđandi í íslensku menntakerfi og pað leiðir til inntökuhindrana á milli grunnskóla og framhaldsskóla, en pó sérstaklega framhaldsskóla og háskóla. Sterk staða bóknámsbrauta dregur nemendur frekar að peim en starfsnámsbrautum, en einnig eru aðrir pættir sem virðast fæla nemendur frá starfsnámsbrautum. Hér má nefna áhrif inntökuskilyrða par sem bóknámsgreinar ráđa för, viðhorf foreldra, búsetu nemenda, kynjahalla starfsgreina sem og lengd og inntak námsbrauta. Einnig má ætla að mikil sérhæfing á starfsnámsbrautum (b.e. lítið val), hversu bundnar pær eru tilteknu starfi og sú staðreynd að nemendur purfi sjálfir að finna samning til að ljúka vinnustaðanámshluta námsbrautarinnar geti mögulega fælt nemendur frá pví að velja starfsnám í framhaldsskóla.

Við bendum pví á að tilraunir til að aftengja stúdentsprófið bóknámsbrautum virðast ekki hafa borið árangur. Einkum og sér í lagi skýrist petta af pví að í lögum um framhaldsskóla er enn litið á stúdentsprófið fyrst og fremst sem undirbúning fyrir háskólanám, enda er pað tilgreint 1 lögum um háskóla (lög um háskóla nr. 63/2006, 19. gr.). Dað er í samræmi við megináherslu skýrslu Starfsnámsnefndar (2006) um að skipulag framhaldsskólans skuli miðast við pað sem á eftir kemur. Nemendur sem eru óvissir um framtíð sína og vilja halda öllum möguleikum opnum sækja pví frekar nám á bóknáms- en starfsnámsbrautum. Рað viðhorf að bóknámsbrautir séu rétti farvegurinn fyrir pá sem stefna á háskólanám virðist pví ekki vera á undanhaldi, prátt fyrir viðleitni stjórnvalda í gegnum tíðina til pess að styrkja stöðu starfsnámsbrauta að pessu leyti. 
Atvinnulífið hefur áhrif á starfsnámsbrautir, bæði með námssamningum á vinnustað og aðkomu að skipulagi námsins í gegnum starfsgreinaráð. Svo virðist sem atvinnulífið hafi ráðið miklu um pað hversu lítill hlutur almennra greina hefur verið í starfsnámi og pannig orðið pess valdandi að starfsnámsbrautir eru síður aðlaðandi fyrir pá sem vilja halda möguleikum opnum og ljúka stúdentsprófi. Hér býr sennilega að baki ákveðin sýn á tilgang náms og að starfsnám sé fyrst og fremst til að undirbúa nemendur undir tiltekin störf, sem krefjist minni áherslu á almenna menntun. Detta viðhorf kristallast í máli eins bóknámskennarans:

Við erum að undirbúa nemendur undir háskólanám, undir pátttöku í samfélaginu okkar, undir pátttöku í lýðræðissamfélaginu okkar og jafnvel vinnumarkaðinn, en, við vitum ekki hver atvinnan verður ... Рað er kannski annað með, ef pú ert með verkgreinanemanda, smiður, pá verður hann smiður.

Tilhneiging virðist pví vera til að skilgreina tilgang starfsnámsbrauta frá töluvert prengra sjónarhorni en bóknámsbrautir, með réttu eða röngu. Niðurstaðan er allavega sú að starfsnámsbrautir virðast síður aðlaðandi fyrir ungmenni en bóknámsbrautir og félagsleg virðingarstaða starfsnáms er almennt, eins og sýnt hefur verið fram á, veikari en bóknáms. Menntakerfi sem lýtur áhrifamætti háskólastigsins par sem áhersla er lögð á námsárangur í fáum, valdamiklum, bóklegum greinum, og nemendur eru almennt hvattir til að halda öllum möguleikum opnum sem lengst, vinnur gegn starfsnámi.

Í pessari greiningu hafa verið skoðuð tiltæk gögn úrýmsum áttum, en brýn pörfer á kerfisbundnum rannsóknum á viðfangsefninu til að skoða orsakir ólíkrar stöðu bóknáms- og starfnámsbrauta og hvaða leiðir eru raunverulega færar til að efla starfsnám á framhaldsskólastigi, sé samkomulag um slíkt. Баð má vitanlega deila um hve brýnt er að efla stöðu tiltekinna starfsnámsgreina. En sé pað stefnan pá skiptir öllu að gera sér skýra grein fyrir pví hverjir áhrifavaldarnir eru, hvort sem er innan framhaldsskólans eða utan hans. Dar verður bæði að horfast 1 augu við pær pversagnir sem birtast pegar grannt er skoðað (sjá einnig Jón Torfa Jónasson, 1994) og pær kerfisvillur sem vinna gegn starfsnáminu.

Hér að framan höfum við sýnt fram á ólíka stöđu bók- og starfsnáms í íslensku framhaldsskólakerfi. Munurinn birtist á fjölmörgum sviðum innan sem utan skólastigsins, bæði kerfislega og samfélagslega, á stjórnsýslustiginu, í stefnumótun og í skólakerfinu, og hann teygir sig inn í kennslustofur og birtist í reynslu kennara. Fjölpættar pversagnir og kerfisvillur koma pví víða fram. Dað hefur jafnframt verið bent á að margt af pví sem nefnt er um núverandi ólíka stöðu er ekki nýtt af nálinni heldur hefur varað um langa hríð. Niðurstöðurnar varpa fram áleitnum og flóknum spurningum um félagslegt réttlæti, og mikilvægi pess að ræða markmið og tilgang menntunar og íhaldssöm viðhorf og áhrif innan menntakerfisins.

\section{Aftanmálsgreinar}

[1] Megingagnasöfnun í rannsókninni Starfshættir í framhaldsskólum fór fram á tímabilinu október 2013 til nóvember 2014 í níu framhaldsskólum, auk pess sem rannsóknartækin voru forprófuð í tíunda skólanum. Gögnin eru vettvangslýsingar á 130 kennslustundum, yfir 60 afrituð viðtöl við nemendur (hópviðtöl), kennara og stjórnendur, ljósmyndir úr kennslustofum, kennsluáætlanir og önnur skrifleg gögn. Fimmtán manna hópur fræðafólks við Menntavísindaog Félagsvísindasvið Háskóla Íslands tók pátt í gagnasöfnuninni. Rannsóknin naut styrkja úr Rannsóknarsjóði Háskóla Íslands á árunum 2013-2015 og frá Norræna öndvegissetrinu Justice Through Education in the Nordic Countries, styrktu af NordForsk, 2013-2018. Við pökkum sérstaklega framhaldsskólunum sem veittu aðgang að starfinu í rannsóknarskyni.

[2] Hér er ekki byggtá sömu flokkun kennslustunda og gert er ráð fyrirírannsóknákennsluaðferðum (sjá Ingvar Sigurgeirsson, Elsu Eiríksdóttur og Ingólf Ásgeir Jóhannesson, 2018). Sú flokkun var unnin út frá nákvæmari skilgreiningum í tilteknu flokkunarkerfi kennsluaðferða, en hér var einungis ætlunin að gefa gróft yfirlit. 


\section{On Parity of Esteem between Vocational and General Academic Programs in Upper Secondary Education in Iceland}

In a European context, there has long been a discussion on the problem of parity of esteem between vocational education and training (VET) and general academic upper secondary education (see for example CEDEFOP, 2014; Lasonen \& Young, 1998; Parkes, 1993). VET education does not enjoy the same status as general academic upper secondary education, which usually provides a pathway to higher education. The disparity of esteem between these two educational pathways reveals itself, for example, in differences in social standing, content taught, and the ability of students entering the programs. This, in turn, has consequences for social justice and future prospects of students (Nylund et al., 2018).

The disparity of esteem has been debated in Iceland for the better part of a century (Jón Torfi Jónasson, 1994). Despite regular declarations from various stakeholders of the need to strengthen VET, little has changed over the years. Jón Torfi Jónasson (1998a) identified the diverse forces working against VET at the upper secondary level in Iceland, some including the very stakeholders vowing support. There have been several attempts to address the apparent parity divide, showing a variety of very deliberate attempts to de-institutionalize the divide between vocational and academic tracks. The most recent examples are the educational reform in Iceland in 2008 and a curriculum overhaul in 2011 (lög um framhaldsskóla [Upper Secondary Education Act] nr. 92/2008; Mennta- og menningarmálaráðuneytið [Ministry of Education, Science and Culture], 2012). A white paper on education reform (Menntaog menningarmálaráðuneytið [Ministry of Education, Science and Culture], 2014), also presented a clear policy directive to enhance the status of vocational education. Despite these efforts, a disparity in esteem between vocational and general academic pathways seems evident and the resilience of the issue begs further investigation.

The aim of the paper is to explore the disparity between vocational and academic programs in contemporary upper secondary education in Iceland from three perspectives: 1) External forces with a focus on educational policy documents, as well as the impact of the university level and the world of work. 2) The setting of upper secondary education and what influences students' choice of upper secondary education. 3) Teaching practices and teacher experiences as compared across these two pathways at upper secondary schools. Considering these three different perspectives provides us with a cross-sectional view of how the disparity potentially reveals itself.

In our analysis we draw upon different sources of data. We used various public documents, including the Act for the upper secondary school level (lög um framhaldsskóla [Upper Secondary Education Act] nr. 92/2008) and the National Curriculum Guide (Mennta- og menningarmálaráðuneytið [Ministry of Education, Science and Culture], 2012). Additionally, we used upper secondary school websites to gauge different admission requirements, as well as examining data from Statistics Iceland. We also used interview data and classroom observations from a comprehensive study conducted in nine upper secondary schools in Iceland between 2013 and 2014 (Gerður G. Óskarsdóttir og rannsóknarhópurinn, 2018). The nine upper secondary schools were selected on the basis of stratified sampling. Here, we used data from 115 classroom observations, interviews with 21 school leaders and 22 teachers to compare teaching practices and analyze participants' perception on the impact of different social structures and stakeholders on these two educational pathways.

Our findings show that a disparity between vocational and general academic upper secondary education still exists in Iceland. The parity of esteem issue reveals itself 
in various ways across the three different perspectives considered. The status of the subjects belonging to vocational education, on the one hand, and general academic education, on the other, is seen to differ when consulting the National Curriculum Guide (Mennta- og menningarmálaráðuneytið [Ministry of Education, Science and Culture], 2012) and the Upper Secondary Education Act (lög um framhaldsskóla) No. 92/2008. The Guide and the Act are silent about individual vocational subjects, while the core subjects, English, mathematics, and Icelandic, are almost exclusively discussed in both public papers. The disparity is, inter alia, inherent in the admission requirements of upper secondary schools. Students enrolling in VET pathways are not required to have as high grades at the end of compulsory education as students enrolling in general academic pathways. In addition, entry requirements are almost exclusively based on academic competences and traditions. The teaching practices and classroom work varied in important ways between the observed VET classes and the more general academic classes. Individualized teaching practices were more common within the VET classes and group work more frequently used in the general academic classes. The VET classes were also of longer duration. The interviews with teachers revealed deep-seated differences in the status of VET and general academic programs, demonstrating that VET teachers generally have the challenge of teaching a more diverse student group, in terms of academic ability, learning disabilities, and age.

Hence, the overall results show that academic trends dominate the system of upper secondary education in Iceland, undermining the status of vocational education. The findings give rise to complex questions on social justice in education, the need to discuss the aims of education, and how a controlling conservative attitude permeates the education system, even though public policy preaches the opposite.

Key words: Vocational education, academic programs, upper secondary education, curriculum, teaching practices, admission requirements

\section{Um höfundana}

Elsa Eiríksdóttir (elsae@hi.is) er dósent í kennslufræði verk- og starfsmenntunar við Menntavísindasvið Háskóla Íslands. Hún lauk BA-prófi í sálfræði frá Háskóla Íslands 1999 og meistara- og doktorsprófi í verkfræðilegri sálfræði frá Georgia Institute of Technology í Atlanta í Bandaríkjunum 2007 og 2011. Rannsóknaráhugi hennar beinist að námi og yfirfærslu, próun kunnáttu og verk- og starfsmenntun.

Guðrún Ragnarsdóttir (gudrunr@hi.is) er lektorá Menntavísindasviði Háskóla Íslands. Guðrún er menntaður lífeindafræðingur (BSc) og er með kennsluréttindi á grunnog framhaldsskólastigi. Að auki er hún með diplómagráđu í opinberri stjórnsýslu, meistaragráðu í lýðheilsufræðum og doktorsgráðu í menntavísindum. Guðrún hefur starfað sem framhaldsskólakennari og millistjórnandi í framhaldsskólum. Einnig hefur hún tekið að sér fjölbreytt verkefni á sviði menntunar fyrir Evrópuráđið. Sérsvið hennar er kennslufræði, skólapróun, starfspróun og stjórnun skóla.

Jón Torfi Jónasson (jtj@hi.is) lauk meistarprófi í tilraunasálfræði með áherslu á hugfræði. Hann lauk doktorsprófi frá háskólanum í Reading á Englandi árið 1980. Hann kenndi sálarfræði náms og hugsunar og aðferðafræði og fjölmargar greinar menntavísinda við Háskóla Íslands frá 1977. Hann starfaði sem prófessor í uppeldisog menntunarfræði til 2017, var deildarforseti félagsvísindadeildar Hí 1995-2001 og forseti menntavísindasviðs Hí 2008-2013. Hann hefur skrifað um fjölmarga pætti skólakerfisins, m.a. um starfsmenntun (sjá http://uni.hi.is/jtj). 


\section{About the authors}

Elsa Eiríksdóttir (elsae@hi.is) is an associate professor at the University of Iceland, School of Education. She completed a BA degree in psychology from the University of Iceland in 1999 and a master's and a PhD in engineering psychology from Georgia Institute of Technology in Atlanta in 2007 and 2011, respectively. Her research interests include learning, transfer of training, skill acquisition, and vocational education and learning.

Guðrún Ragnarsdóttir (gudrunr@hi.is) is assistant professor at the University of Iceland, School of Education. Guðrún holds a BSc degree in biomedical science and two diplomas, one in in education and another in public administration. She has also completed a master's degree in public health and a $\mathrm{PhD}$ in education from the University of Iceland, School of Education. Guðrún has worked as a compulsory school teacher, upper secondary teacher and a school leader, as well as having been employed as a teacher trainer for the Council of Europe. Her research interests include pedagogy, school development, professional development, and school leadership.

Jón Torfi Jónasson(jtj@hi.is) became professor of education at the University of Iceland in 1993 and was Dean of the Faculty of Social Sciences, 1995-2001. In 2008 he became the Dean of the School of Education when it was merged with the University of Iceland. In recent years, he has studied the problem of drop-out in Iceland and has also written on different levels of education; that is, pre-primary, compulsory, uppersecondary (both academic and vocational), tertiary education, teacher education and adult education - in many cases from a comparative, esp. Nordic, perspective (see http://uni.hi.is/jtj/en/ )

\section{Heimildir}

Arnesen, A.-L. og Lundahl, L. (2006). Still social and democratic? Inclusive education policies in the Nordic welfare states. Scandinavian Journal of Educational Research, 50(3), 285-300.

Bernstein, B. (2000). Pedagogy, symbolic control and identity. Lanham: Rowman \& Littlefield Publishers.

Bleazby,J. (2015). Why some school subjects have a higher status than others: The epistemology of the traditional curriculum hierarchy. Oxford Review of Education, 41(5), 671-689. doi:10.1080/03054985.2015.1090966

Braun, A., Ball, S. J., Maguire, M. og Hoskins, K. (2011). Taking context seriously: Towards explaining policy enactments in the secondary school. Discourse: Studies in the Cultural Politics of Education, 32(4), 585-596.

Braun,V. og Clarke, V. (2006). Using thematic analysis in psychology. Qualitative Research in Psychology, 3(4), 77-101.

CEDEFOP. (2014). Attractiveness of initial vocational education and training: Identifying what matters. Luxembourg: Publications Office of the European Union.

Deng, Z. (2013). School subjects and academic disciplines. The differences. Í A. Luke, A. Woods og K. Weir (ritstjórar), Curriculum syllabus design and equity. A primer and model (bls. 40-53). New York: Routledge.

Down, B., Smyth, J. og Robinson, J. (2017). Problematising vocational education and training in schools: Using student narratives to interrupt neoliberal ideology. Critical Studies in Education, (í prentun), 1-19. doi:10.1080/17508487.2017.1289474

Efnahags- og framfarastofnunin [OECD]. (1987). Skýrsla um menntastefnu á Íslandi. Reykjavík: Menntamálaráðuneytið.

Elsa Eiríksdóttir. (2017). Nám í skóla og á vinnustað: Viðhorf og reynsla sveina, kennara og meistara af tvískiptu kerfi löggiltra iðngreina. Tímarit um uppeldi og menntun, 26(1-2), 43-64. doi: 10.24270/tuuom.2017.26.3

Elsa Eiríksdóttir og Rosvall, P-Å. (2018). VET teachers' interpretations of individualisation and relevant knowledge - cross-cultural analysis in two Nordic countries [handrit sent til útgáfu]. 
Fræðsluráð Reykjavíkur. (1971, júlí). Sameinaður framhaldsskóli. Tillögur og greinargerð Fræðsluráds Reykjavíkur um stofnun tilraunaskóla á gagnfreeða- og menntaskólastigi. Reykjavík: Fræðsluskrifstofa Reykjavíkur. [Jóhann S. Hannesson skólameistari er höfundur skýrslunnar].

Gerður G. Óskarsdóttir og rannsóknarhópurinn. (2018). Starfshættir í framhaldsskólum: Aðdragandi og framkvæmd rannsóknar 2012-2018. Netla - Veftímarit um uppeldi og menntun. Sótt af http://netla.hi.is/

Gestur Guðmundsson. (1993). Dróun starfsmenntunar á framhaldsskólastigi. Reykjavík: Menntamálaráðuneytið, Sammennt.

Guðrún Ragnarsdóttir. (2018). School leaders' perceptions of contemporary change at the upper secondary school level in Iceland: Interaction of actors and social structures facilitating or constraining change (óutgefin doktorsritgerð). Háskóli Íslands, Reykjavík.

Gunnar M. Magnússon. (1946). Um menntamál á Íslandi 1944-1946: Greinargerd um löggjöf, framkvamdir og nestu verkefni. Reykjavík: Menntamálaráðuneytið.

Hagstofa Íslands. (2018a). Nýnemum fækkar í starfsnámi á framhaldsskólastigi. Sótt af https://hagstofa.is/ utgafur/frettasafn/menntun/nynemar-a-framhaldsskolastigi-1997-2016/

Hagstofa Íslands. (2018b). Talnaefni: Framhaldsskólastig - Nemendur. Sótt af https://hagstofa.is/talnaefni/ samfelag/menntun/framhaldsskolastig/

Háskóli Íslands. (2018a). Inntökupróf - A-próf. Sótt af https://www.hi.is/felagsvisindasvid_lagadeild_grunnnam/inntokuprof_a_prof

Háskóli Íslands. (2018b). Inntökupróf. Sótt af https://www.hi.is/laeknadeild/inntokuprof

Háskóli Íslands (2018c). Hvað er A-próf og til hvers er pað notað? Sótt af https://www.hi.is/a_prof

Hodge, S., Holford, J., Milana M., Waller, R. og Webb, S. (2017).Vocational education and the field of lifelong education. International Journal of Lifelong Education, 36(3), 251-253. doi: 10.1080/02601370.2017.1306357

Ingvar Sigurgeirsson, Ingólfur Ásgeir Jóhannesson og Elsa Eiríksdóttir (2018). Kennsluaðferðir í 130 kennslustundum í framhaldsskólum. Netla - Veftímarit um uppeldi og menntun. Sótt af http://netla.hi.is/

Jón Torfi Jónasson. (1992). Próun framhaldsskólans: Frá starfsmenntun til almenns bóknáms. Uppeldi og menntun:Tímarit Kennaraháskóla Íslands, 1(1), 173-189.

Jón Torfi Jónasson. (1994). Skipt um skoðun. Um flutning nemenda á milli priggja flokka námsbrauta í framhaldsskóla. Uppeldi og menntun: Tímarit Kennaraháskóla Íslands, 3(1), 63-82.

Jón Torfi Jónasson. (1995). Baráttan á milli bóknáms og starfsmenntunar á framhaldsskólastigi. Í Friðrik H. Jónsson (ritstjóri), Rannsóknir í félagsvísindum: Erindi flutt á rádstefnu í september 1994 (bls. 277-285). Reykjavík: Félagsvísindastofnun HÍ, Hagfræðistofnun HÍ, Háskólaútgáfan.

Jón Torfi Jónasson. (1997). Djóđsögur úr skólakerfinu. Íslensk félagsrit, 7-8, 41-69.

Jón Torfi Jónasson. (1998a). The foes of Icelandic vocational education at the upper secondary level. Í A. Tjeldvoll (ritstjóri), Education and the scandinavian welfare state in the year 2000 (bls. 267-304). New York: Garland Publishing.

Jón Torfi Jónasson. (1998b). Upphaf nútíma menntakerfis á Íslandi. Í Guðmundur J. Guðmundsson og Eiríkur K. Björnsson (ritstjórar), Íslenska sögupingið, 30. 5.1997 (bls. 355-358). Reykjavík: Sagnfræðistofnun HÍ, Sagnfræðingafélag Íslands.

Jón Torfi Jónasson. (2003). Does the state expand schooling? A study based on five Nordic countries. Comparative Education Review, 47(2), 160-183.

Jón Torfi Jónasson. (2008a). Fjöldi nemenda og fjármagn. Í Loftur Guttormsson (ritstjóri), Almenningsfraðsla á Íslandi 1880-2007: Sídara bindi, Skóli fyrir alla 1947-2007 (bls. 176-194). Reykjavík: Háskólaútgáfan.

Jón Torfi Jónasson. (2008b). Samræmdur framhaldsskóli í mótun. Í Loftur Guttormsson (ritstjóri), Almenningsfraèsla á Íslandi 1880-2007: Síðara bindi, Skóli fyrir alla 1947-2007 (bls. 157-173). Reykjavík: Háskólaútgáfan.

Kristín Bjarnadóttir. (2007). Nokkur tímamót í sögu íslenskrar stærðfræðimenntunar. Tímarit um menntarannsóknir, 4, 7-22.

Kristjana Stella Blöndal, Jón Torfi Jónasson og Sólrún Sigvaldadóttir. (2016). Sérkenni námsferils starfsnámsnemenda í framhaldsskóla. Afstaða og skuldbinding til náms, líðan og stuðningur foreldra og skóla. Sótt af http:// menntavisindastofnun.hi.is/sites/menntavisindastofnun.hi.is/files/serkenni_starfsnams.pdf

Kvale, S. og Brinkmann, S. (2009). Interviews: Learning the craft of qualitative research interviewing (2. útgáfa). Thousand Oaks: Sage. 
Lasonen, J. og Young, M. (ritstjórar). (1998). Strategies for achieving parity of esteem in European upper secondary education. Jyväskylä, Finnland: Institute for Educational Research, University of Jyväskylä.

Lög um framhaldsskóla nr. 80/1996.

Lög um framhaldsskóla nr. 92/2008.

Lög um gagnfræðanám nr. 48/1946.

Lög um háskóla nr. 63/2006.

Lög um menntun og ráðningu kennara og skólastjórnenda við leikskóla, grunnskóla og framhaldsskóla nr. $87 / 2008$.

Matthías Jónasson. (1949).Verknámsdeild: Nokkrar athugasemdir og tillögur. Menntamál:Tímarit um uppeldisog skólamál, 22, 1-44.

Mennta- og menningarmálaráđuneytið. (2012). Aðalnámskrá framhaldsskóla. Almennur hluti. Reykjavík: Höfundur.

Mennta- og menningarmálaráđuneytið. (2014). Hvítbók um umbatur í menntun. Reykjavík: Höfundur.

Menntamálastofnun. (2018a, 24. apríl). Helmingur telur verknám henta sér betur. Sótt af https://mms.is/frettir/ helmingur-telur-verknam-henta-ser-betur

Menntamálastofnun. (2018b, 28. september). Staðfestar námsbrautalýsingar. Sótt af https://mms.is/stadfestar-namsbrautalysingar

Menntamálaráðherra. (1995). Frumvarp til laga um framhaldsskóla. Stjórnarfrumvarp. 120. löggjafarping. - 94. mál. Sótt af https://www.althingi.is/altext/120/s/0096.html

Menntamálaráđherra. (2007). Frumvarp til laga um framhaldsskóla. Stjórnarfrumvarp. Pskj. 320 - 286. mál. Sótt af https://www.althingi.is/altext/135/s/0320.htmlMenntaskólinn á Ísafirði. (e.d.). Inntökuskilyrði inn í MÍ. Sótt af http://misa.is/namid/inntokuskilyrdi/

Nylund, M., Rosvall, P.-Å., Elsa Eiríksdóttir, Holm, A.-S., Isopahkala-Bouret, U., Niemi A.-M. og Guðrún Ragnarsdóttir. (2018). The academic-vocational divide in three Nordic countries: Implications for social class and gender. Education Inquiry, 9(1), 97-121. doi: 10.1080/20004508.2018.1424490

Parkes, D. (1993). Parity of esteem for vocational education? European Journal of Education, 28(2), 131-134.

Reglugerð um inntak menntunar leik-, grunn- og framhaldsskólakennara nr. 872/2009.

Reglugerð um skipan og störf starfsgreinaráða nr. 711/2009.

Ríkisendurskoðun. (2017). Starfsmenntun á framhaldsskólastigi: Skipulag og stjórnsýsla. Sótt af https://rikisendurskodun.is/wp-content/uploads/2017/04/SU-Starfsmenntun-a-framhaldsskolastigi.pdf

Starfsgreinanefnd. (2012). Bréf til mennta- og menningarmálaráðherra frá starfsgreinanefnd um voegi almennra bóknámsgreina á námsbrautum starfsgreina. Reykjavík: Höfundur.

Starfsnámsnefnd. (2006). Nýr framhaldsskóli. Skýrsla Starfsnámsnefndar. Reykjavík: Höfundur.

Stjórnarráðið. (2017). Sáttmáli Framsóknarflokks, Sjálfstceðisflokks og Vinstri hreyfingarinnar-grans framboðs um ríkisstjórnarsamstarf og eflingu Alpingis. Sótt af https://www.stjornarradid.is/lisalib/getfile.aspx?itemid=a5aa63d9d5b4-11e7-9422-005056bc530c

Wheelahan, L. (2007). How competency-based training locks the working class out of powerful knowledge: A modified Bernsteinian analysis. Review of British Journal of Sociology of Education, 28(5), 637-650.

Wheelahan, L. (2015) Not just skills: What a focus on knowledge means for vocational education. Journal of Curriculum Studies, 47(6), 750-762. doi: 10.1080/00220272.2015.1089942

Pröstur Pór Ólafsson. (2017). Áhrif staðsetningar framhaldsskóla á námsval: Velja nemendur að fara að heiman í starfsnám ef bóknám er í bođi í noesta nágrenni? (óútgefin B.Ed.-ritgerð). Háskóli Íslands, Reykjavík. Sótt af http://hdl.handle.net/1946/29213

Elsa Eiríksdóttir, Guðrún Ragnarsdóttir og Jón Torfi Jónasson. (2018).

Dversagnir og kerfisvillur? Kortlagning á ólíkri stöðu bóknáms- og starfsnámsbrauta á framhaldsskólastigi.

Netla - veftímarit um uppeldi og menntun. Sérrit 2018 - Framhaldsskólinn í brennidepli. Menntavísindasvið Háskóla Íslands.

Sótt af http://netla.hi.is/serrit/2018/framhaldskolinn_brennidepli/07.pdf

DOI: https://doi.org/10.24270/serritnetla.2019.7 